\title{
Platinum(II) and palladium(II) complexes with electron-deficient meso- diethoxyphosphorylporphyrins: synthesis, structure and tuning of photophysical properties by varying peripheral substituents
}

\author{
Marina V. Volostnykh, ${ }^{a}$ Sergey M. Borisov, ${ }^{* b}$ Mikhail A. Konovalov, ${ }^{\text {a,c,d }}$ Anna A. Sinelshchikova, ${ }^{a}$ Yulia G. \\ Gorbunova, ${ }^{* a, d}$ Aslan Yu. Tsivadze, ${ }^{\text {a,d }}$ Michel Meyer, ${ }^{e}$ Christine Stern, ${ }^{e}$ Alla Bessmertnykh-Lemeune*e
}

\begin{abstract}
a Frumkin Institute of Physical Chemistry and Electrochemistry, Russian Academy of Sciences, Leninsky pr. 31-4, Moscow, 119071, Russia. E-mail: yulia\#igc.ras.ru

${ }^{b}$ Institute of Analytical Chemistry and Food Chemistry, Graz University of Technology, Stremayrgasse 9, A-8010 Graz, Austria. E-mail: sergey.borisov@tugraz.at

' Chemistry Department, Lomonosov Moscow State University, Leninskie Gory 1/3, Moscow, 119991, Russia Kurnakov Institute of General and Inorganic Chemistry, Russian Academy of Sciences, Leninsky pr. 31, Moscow, 119991, Russia

'Institut de Chimie Moléculaire de I'Université de Bourgogne (ICMUB), UMR 6302 CNRS, Université Bourgogne Franche-Comté, 9 Avenue Alain Savary, BP 47870, 21078 Dijon Cedex, France. E-mail: Alla.Lemeune@ubourgogne.fr

${ }^{e}$ Electronic Supplementary Information (ESI) available: $1 \mathrm{H}, 13 \mathrm{C}$, and 31P NMR spectra, MALDI-TOF and ESI-HR mass spectra of all prepared complexes, X-ray crystal data, emission spectra and photophysical properties of the Pt and Pd porphyrinates, photodegradation kinetic data. See DOI: 10.1039/x0xx00000x
\end{abstract}

A series of electron-deficient platinum(II) and palladium(II) meso-(diethoxyphosphoryl)porphyrins, namely [10(diethoxyphosphoryl)-5,15-bis( $p$-tolyl)porphyrinato]palladium(II) (PdDTolPP), \{10-(diethoxyphosphoryl)-5,15bis $[p$-(methoxycarbonyl)phenyl]porphyrinato palladium(II) [PdD(CMP)PP], [10-(diethoxyphosphoryl)-5,15dimesitylporphyrinato]palladium(II) [5-(diethoxyphosphoryl)-10,15,20trimesitylporphyrinato]palladium(II) (PdTMesPP) and the corresponding platinum(II) compounds, were synthesized and structurally characterized in solution by means of ${ }^{1} \mathrm{H},{ }^{13} \mathrm{C},{ }^{31} \mathrm{P}$ NMR spectroscopies and in the solid state by single crystal X-ray diffraction [PdDTolPP, PdD(CMP)PP and PtD(CMP)PP]. Their optical and photophysical properties (UV-vis absorption, luminescence and excitation spectra, phosphorescence quantum yields and lifetimes) were also determined. The complexes under investigation emit at room temperature in the near-infrared region (670-770 nm). Phosphorescence quantum yields of the palladium(II) meso-phosphorylated porphyrins lie in the range of 3.4 to $5.8 \%$, with lifetimes of 633 to $858 \mu \mathrm{s}$ in deoxygenated toluene solutions at room temperature. The corresponding platinum(II) complexes exhibit phosphorescence quantum yields in the range of 9.2 to $11 \%$, with luminescence decay times of 56 to $69 \mu$ s. Moreover, effective homogeneous oxygen quenching and the good sensitivity in toluene $\left(\sim 155 \mathrm{~Pa}^{-1} \mathrm{~s}^{-1}\right)$ were observed for the platinum(II) complexes with phosphorylporphyrins in solution. Investigations of the photostability of porphyrinylposphonates and related complexes lacking a phosphoryl group in DMF under irradiation in air using a $400 \mathrm{~W}$ vis-NIR lamp demonstrated 
that photobleaching is strongly dependent on the substituents at the periphery of the macrocycle. Platinum and palladium trimesitylphosphorylporphyrins PdTMesPP and PtTMesPP exhibit a high photostability in DMF solution and seem to be the most potentially interesting derivatives of the series for oxygen sensing in biological samples and the covalent immobilization on solid supports to prepare sensing devices including optic fibers.

Platinum(II) and palladium(II) porphyrins are very attractive luminophores due to their strong room temperature phosphorescence and large Stokes shifts. ${ }^{1}$ They have found useful applications in OLEDs, ${ }^{2}$ photovoltaics, ${ }^{3}$ as singlet oxygen sensitizers for photodynamic therapy ${ }^{4}$ and photocatalysis, ${ }^{5}$ as well as labels in living cells. ${ }^{6-8}$ Efficient quenching of their phosphorescence by molecular oxygen enables the optical oxygen sensing. ${ }^{8-10}$ The quantitative measurement of dioxygen levels by these compounds relies on monitoring the changes of either the emission intensity or the lifetime of the longlived triplet excited state induced by the interactions of the excited chromophore with $\mathrm{O}_{2}$ molecules. ${ }^{11,12}$ When phosphorescent compounds are used for oxygen sensing, their photostability is of particular importance because the mechanisms of oxygen signalling and chromophore photobleaching involve several common processes. Reactive oxygen species (ROS: superoxide anion radical and singlet oxygen) generated during the detection process can react with the porphyrin molecules leading to their degradation. Alternatively, the triplet state itself can be involved in various photo-induced reactions. ${ }^{13}$ These chemical processes could impair the accurate determination of the dioxygen concentration in the studied sample.

$\mathrm{Pt}(\mathrm{II})$ and $\mathrm{Pd}(\mathrm{II})$ complexes with octaethylporphyrin (OEP) are commonly used phosphorescent indicators among the tetrapyrrolic compounds, since they possess high brightness. ${ }^{14-16}$ However the stability of OEP complexes toward oxidative degradation is quite low. It was shown that the presence of electron-withdrawing groups $(\mathrm{Br}, \mathrm{CN}$, and $\mathrm{NO}_{2}$ ) has a pronounced effect on the electro-chemical properties of porphyrin rings, ${ }^{17-19}$ in particular, it makes them easily reducible and difficult to oxidize relative to the unsubstituted porphyrin. Therefore, for most applications $\mathrm{Pt}(\mathrm{II})$ and $\mathrm{Pd}(\mathrm{II})$ complexes with halogen-substituted TPP ligands such as, $\mathbf{H}_{2} \mathbf{F}_{20}$ TPP $[5,10,15,20$ tetra(pentafluorophenyl)porphyrin $] \quad$ or $\quad \mathbf{H}_{2} \mathbf{F}_{\mathbf{2 8}} \mathbf{T P P} \quad[3,4,7,8,12,13,17,18$-octafluoro5,10,15,20-tetra(pentafluorophenyl)porphyrin], which are robust towards oxidation, are successfully used. ${ }^{11,20-22} \pi$-Extended porphyrins [e.g. tetrabenzoporphyrins $(\mathbf{T B P})^{23}$ or tetranaphtoporphyrins (TNP) $)^{24}$ ] have also been intensively investigated in the field of optical sensing materials. These compounds are excitable in the red and NIR part of the 
electromagnetic spectrum and possess a moderate to high brightness. For increasing the photostability of TBP and TNP to oxidation by ${ }^{1} \mathrm{O}_{2}$ and other ROS, the general strategy of incorporating electron-withdrawing groups into the luminophore structure can also be applied. ${ }^{25,26}$

To the best of our knowledge, no photophysical data for electron-deficient luminescent porphyrins substituted with phosphoryl groups have been reported yet, because convenient synthetic methods for their preparation were developed only recently. ${ }^{27-30}$ Nevertheless, in a few studies it was demonstrated that the introduction of one or more electron-withdrawing $\mathrm{P}(\mathrm{O})(\mathrm{OR})_{2}$ (where $\mathrm{R}$ is an alkyl group) groups directly attached to the porphyrin core at either $\beta$-pyrrolic or meso-positions leads to positive shifts of the redox potentials. ${ }^{31-34}$ It makes platinum(II) and palladium(II) complexes with phosphorylporphyrins promising candidates for the development of photostable oxygen sensing materials. Moreover, meso(diethoxyphosphoryl)porphyrinates are of particular interest for the preparation of functional materials, because their chemical modifications allow to obtain water-soluble derivatives ${ }^{29}$ and compounds with anchoring groups for subsequent grafting onto $\mathrm{SiO}_{2}$ surfaces and metal oxide supports. ${ }^{35-40}$ In this work, we describe the synthesis, structural characterization, and photophysical properties of the novel phosphorescent mesosubstituted $\mathrm{Pt}(\mathrm{II})$ and $\mathrm{Pd}(\mathrm{II})$ phosphorylporphyrins. We examine the impact of introducing an electron-withdrawing $\mathrm{P}(\mathrm{O})(\mathrm{OEt})_{2}$ group and aryl substituents at mesopositions on the photophysical characteristics of the platino- and palladoporphyrins, including their photostability, as well as their sensitivity of molecular oxygen detection in solution.

\section{Results and discussion}

\section{Synthesis and characterization of the Pt(II) and Pd(II) complexes}

The phosphorescent $\mathrm{Pt}(\mathrm{II})$ and $\mathrm{Pd}(\mathrm{II})$ complexes with meso-phosphorylated porphyrins $\left[\mathbf{M R}^{1} \mathbf{P P}-\mathbf{M R}^{4} \mathbf{P P}\right.$, with $\mathrm{R}^{1}=\mathrm{DTol}, \mathrm{R}^{2}=\mathrm{D}(\mathrm{CMP}), \mathrm{R}^{3}=\mathrm{DMes}$, and $\mathrm{R}^{4}=\mathrm{TMes} ; \mathrm{M}=\mathrm{Pt}(\mathrm{II})$ and $\operatorname{Pd}(\mathrm{II})$ ] (Chart 1) were prepared in three steps: formation of the zinc(II) phosphorylated complexes, removal of $\mathrm{Zn}^{2+}$ in acidic media, and subsequent complexation with the appropriate metal cations. The zinc(II) phosphorylporphyrins $\left(\mathbf{Z n R} \mathbf{R}^{\mathbf{1}} \mathbf{P} \mathbf{P}-\mathbf{Z} \mathbf{n} \mathbf{R}^{\mathbf{4}} \mathbf{P P}\right)$ were obtained using a described procedure, ${ }^{29}$ with subsequent treatment with $\mathrm{HCl}$ for metal removing. For 
palladium(II) insertion, the synthetic procedure was slightly modified ${ }^{41-44}$ by refluxing the solution of free-base porphyrin with $\mathrm{Pd}(\mathrm{OAc})_{2}$ in acetonitrile instead of the $\mathrm{CHCl}_{3} / \mathrm{MeOH}$ mixture, ${ }^{45}$ in which reduction of $\mathrm{Pd}(\mathrm{OAc})_{2}$ by $\mathrm{MeOH}$ occurs. ${ }^{46}$ The replacement of $\mathrm{MeOH}$ by acetonitrile enabled to obtain all targeted complexes $\mathbf{P d R} \mathbf{R}^{\mathbf{1}} \mathbf{P P}-\mathbf{P} \mathbf{d R}^{\mathbf{4}} \mathbf{P P}$ in nearly quantitative yields (91-100\%), although the reduction of palladium acetate is still observed to some extend and an excess of the palladium salt should be employed to achieve a complete complex formation.

Platinum(II) complexes with the phosphorylated porphyrins $\mathbf{P t R}^{\mathbf{1}} \mathbf{P P}-\mathbf{P t R}^{\mathbf{2}} \mathbf{P P}$ were prepared according to a published procedure ${ }^{47-49}$ by reacting the corresponding freebase porphyrins $\mathbf{H}_{2} \mathbf{R}^{1} \mathbf{P P}-\mathbf{H}_{2} \mathbf{R}^{4} \mathbf{P P}$ with $\mathrm{PtCl}_{2}$ in boiling benzonitrile under argon. Complexes PtDTolPP and PtD(CMP)PP were obtained in 85 and $70 \%$ yield, respectively. Surprisingly, $\mathbf{H}_{2}$ DMesPP and $\mathbf{H}_{2}$ TMesPP were less reactive than $\mathrm{H}_{2}$ DTolPP and $\mathbf{H}_{2} \mathrm{D}(\mathrm{CMP}) \mathbf{P P}$ porphyrins. In spite of prolonged heating and larger amounts of $\mathrm{PtCl}_{2}$, PtDMesP could only be isolated in $18 \%$ yield. When complexation of $\mathbf{H}_{2}$ TMesPP was performed under the same conditions, the starting compound was also completely consumed, but the non-phosphorylated complex PtTMesP was only isolated in low yield (15\%), because of $\mathrm{C}-\mathrm{P}$ bond breaking. This side reaction has already been observed for porphyrinylphosphonate diesters under acidic conditions. ${ }^{34,49}$ When sodium acetate was added to the reaction mixture to prevent a $\mathrm{pH}$ increase during the course of the metal insertion, complexation proceeded smoothly even at $150{ }^{\circ} \mathrm{C}$, affording the desired product in $89 \%$ yield.

The reference compounds, namely the Pt(II) and Pd(II) complexes with the nonphosphorylated porphyrins ( $\mathbf{M R}^{\mathbf{1}} \mathbf{P}-\mathbf{M R}^{\mathbf{4}} \mathbf{P}$, Chart 1), have not been described in the literature so far, excepted for the PdDTolP complex that was presented without full characterization by Ouyang et al..$^{50}$ as a side product of the oxidative coupling of metal chlorins. Herein, these complexes were obtained for the first time from the free-base $\mathrm{A}_{2}$ type porphyrins by the aforementioned procedures for complexation (see the Experimental Section). 


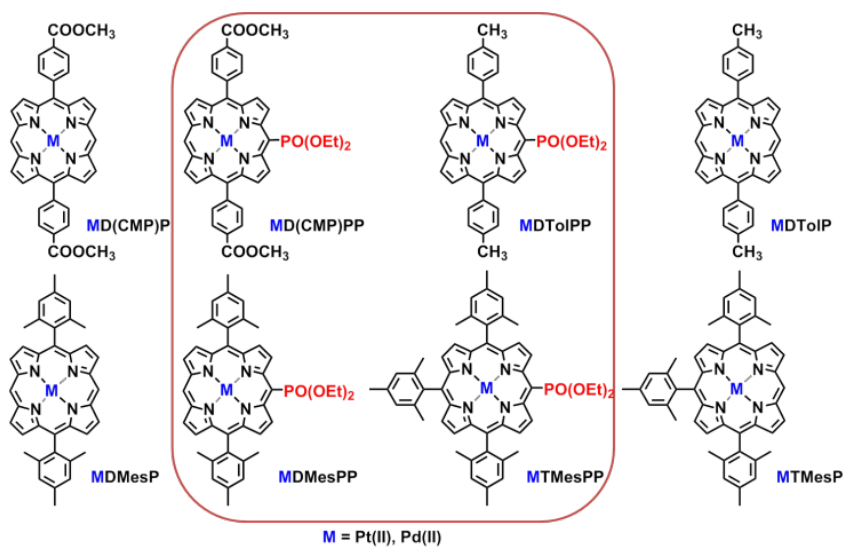

Chart 1. Chemical structures of the investigated phosphorylated Pt(II) and Pd(II) porphyrins MR1PP-MR4PP and of the corresponding reference compounds MR1P-MR4P.

All isolated platinum(II) and palladium(II) porphyrinates were characterized in solution by ${ }^{1} \mathrm{H}$ and ${ }^{31} \mathrm{P}$ NMR and UV-vis spectroscopies, as well as mass spectrometry (MALDI-TOF and HR-ESI; see the Experimental Section and ESI). ${ }^{1} \mathrm{H},{ }^{13} \mathrm{C}$, and ${ }^{31} \mathrm{P}$ NMR spectra of $\mathbf{M R}^{\mathbf{1}} \mathbf{P}-\mathbf{M R}^{4} \mathbf{P}$ and $\mathbf{M R}^{\mathbf{1}} \mathbf{P P}-\mathbf{M R}^{4} \mathbf{P P}$ in $\mathrm{CDCl}_{3}$ or $\mathrm{CDCl}_{3} / \mathrm{CD}_{3} \mathrm{OD}$ mixture $(2: 1 \mathrm{v} / \mathrm{v})$ were in accordance with the proposed structures of the compounds (Figures S3-S6, S11-S16, S19-S22, S27-S32 in the ESI). In the IR spectra of the $\mathbf{M R}^{1} \mathbf{P P}-\mathbf{M R}^{4} \mathbf{P P}$ porphyrins (Figures S63-S66, S71-S74 in the ESI), intense signals at $\sim 950, \sim 1050$, and $\sim 1250 \mathrm{~cm}^{-1}$ were observed in addition to the basic characteristic bands of the porphyrin macrocycles and aryl substituents. Since these features are absent in the spectra of the respective reference compounds $\mathbf{M R}^{\mathbf{1}} \mathbf{P}-\mathbf{M R}^{\mathbf{4}} \mathbf{P}$ (Figures S59-S62, S67$\mathrm{S} 70$ in the ESI), they are assigned to the $\mathrm{P}=\mathrm{O}$ and $\mathrm{P}-\mathrm{O}$ vibrations of the phosphonate group (see the Experimental Section).

Single crystals for three complexes, namely PdDTolPP, PdD(CMP)PP, and PtD(CMP)PP, were grown by slow diffusion of $n$-hexane into a solution of the corresponding compound in dichloromethane or chloroform. The structures were determined by single crystal X-ray diffraction analysis performed at $100 \mathrm{~K}$. The summary of the crystallographic data is presented in Table S1 (ESI). All complexes crystallized as solvates in the triclinic $P-1$ space group. The asymmetric unit includes one porphyrin molecule and one solvent molecule: $\mathrm{CH}_{2} \mathrm{Cl}_{2}$ for PdDTolPP, or $\mathrm{CHCl}_{3}$ for PdD(CMP)PP and PtD(CMP)PP (Fig. 1). Platinum(II) and palladium(II) complexes with the same porphyrin $[\mathbf{P d D}(\mathbf{C M P}) \mathbf{P P}$ and PtD(CMP)PP] are isostructural with very close unit cell parameters (Fig. 1 and Table S1, ESI). The molecular structures of the 
three characterized complexes are typical for palladium(II) and platinum(II) porphyrins. The metal centers have a square-planar coordination geometry formed by four pyrrole nitrogen atoms. The palladium and platinum atoms are nearly coplanar with the $\mathrm{N}_{4}$ plane of the porphyrin core with a slight displacement of 0.0124(9), 0.011(1), and 0.011(1) $\AA$ for PdDTolPP, PdD(CMP)PP, and PtD(CMP)PP, respectively. The mean metalnitrogen distances are 2.016, 2.018, and $2.019 \AA$ for PdDTolPP, PdD(CMP)PP, and PtD(CMP)PP, respectively, which is comparable to the metal-nitrogen distances reported for other palladium(II) and platinum(II) porphyrins. ${ }^{21,45,51,52}$ The molecular structure of the palladium complex with $p$-tolyl substituted porphyrin PdDTolPP reveals a slightly ruffled conformation of the macrocycle, in contrast to the virtually planar porphyrin core found for PdD(CMP)PP and PtD(CMP)PP. Perspective views along the porphyrin plane are shown in Fig. 1. The largest deviations from the porphyrin $\mathrm{N}_{4}$ mean plane are observed for the meso-carbon $\mathrm{C}(14)[0.268(3) \AA]$ and $\beta$-carbon $\mathrm{C}(2)$ [0.248(4) $\AA]$ atoms in the PdDTolPP crystal structure. In case of PdD(CMP)PP and $\operatorname{PtD(CMP)PP,~the~macroheterocycle~is~more~flat~and~the~largest~deviations~are~observed~}$ for the -carbon atoms closest to the phosphoryl substituent $[0.151(4) \AA$ and $0.141(4)$ $\AA$, respectively].

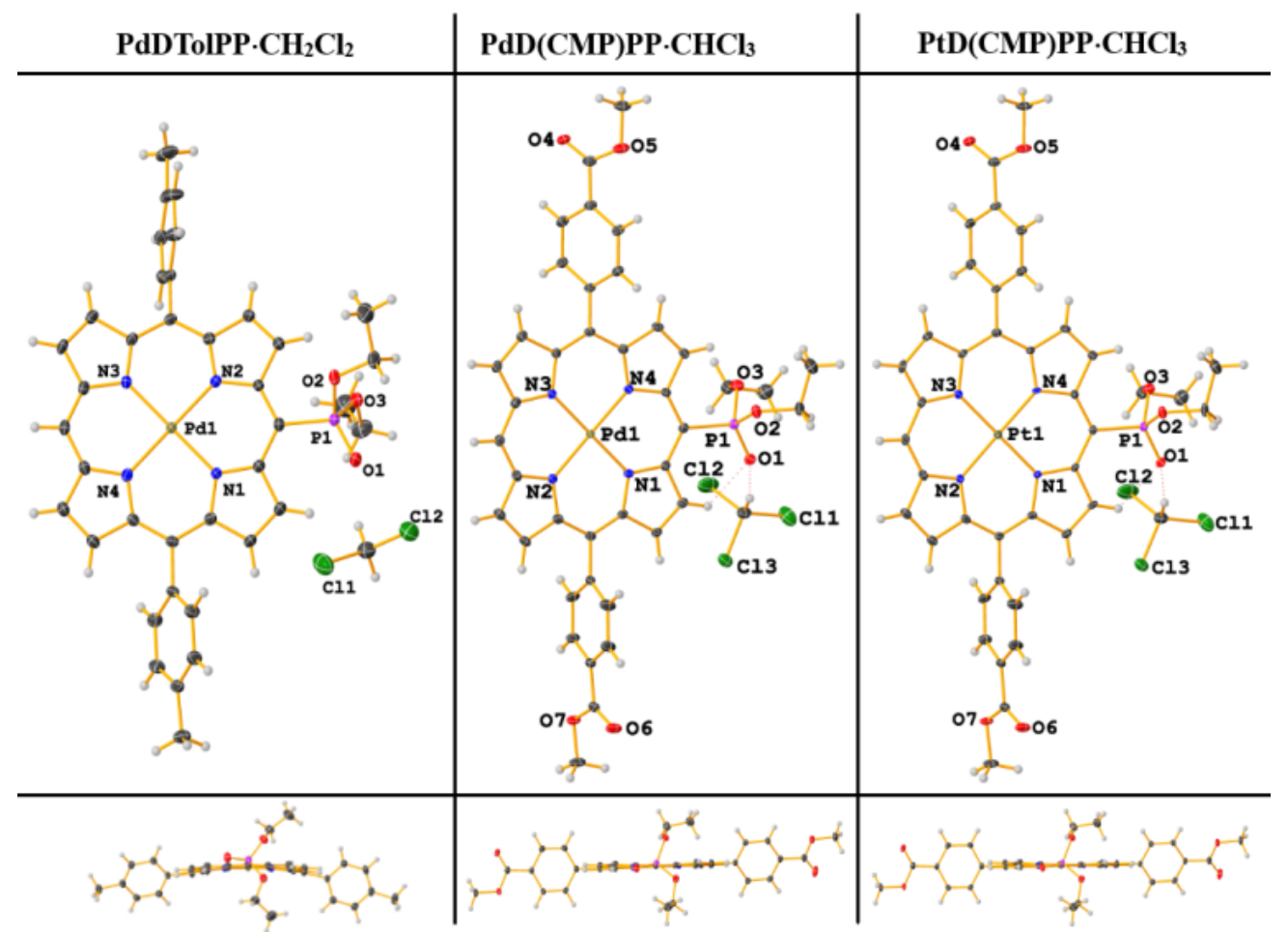

Fig. 1 The asymmetric unit and respective view along the porphyrin plane of PdDTolPP. $\mathrm{CH}_{2} \mathrm{Cl}_{2} \quad($ left), $\mathrm{PdD}\left(\mathrm{CMP}\right.$ )PP. $\mathrm{CHCl}_{3}$ (middle) and PtD(CMP)PP. $\mathrm{CHCl}_{3}$ (right) and respective view along the porphyrin plane. Thermal ellipsoids are at the $50 \%$ probability level. 
In all structures, the phosphoryl group is twisted with respect to the $\mathrm{N}_{4}$ plane in such a way that the $\mathrm{P}=\mathrm{O}$ bond lies almost in the mean porphyrin plane, forming an intramolecular $\mathrm{C}_{\beta}-\mathrm{H} \cdots \mathrm{O}$ hydrogen bond [PdDTolPP: $\mathrm{C}(3) \cdots \mathrm{O}(1)=2.857 \AA$, angle $\mathrm{C}(3)-\mathrm{H}(3) \cdots \mathrm{O}(1)=124.9^{\circ} ; \quad$ PdD(CMP)PP: $\mathrm{C}(3) \cdots \mathrm{O}(1)=2.851 \AA$, angle $\mathrm{C}(3)-$ $\mathrm{H}(3) \cdots \mathrm{O}(1)=127.2^{\circ}$; PtD(CMP)PP: $\mathrm{C}(3) \cdots \mathrm{O}(1)=2.857 \AA$, angle $\mathrm{C}(3)-\mathrm{H}(3) \cdots \mathrm{O}(1)=$ 127.2 ${ }^{\circ}$. The ethoxy groups point out above and below the porphyrin plane (Fig. 1). The torsion angles $\mathrm{O}(1)-\mathrm{P}(1)-\mathrm{C}(1)-\mathrm{C}(2)$ are $1.63,14.1$, and $13.8^{\circ}$ for PdDTolPP, PdD(CMP)PP, and PtD(CMP)PP, respectively. The P-O bond distances of 1.467(2)1.472(2) $\AA$ (for $\mathrm{P}=\mathrm{O}$ ) and 1.568(2)-1.586(2) $\AA$ (for $\mathrm{P}-\mathrm{O}$ ) are typical for mesosubstituted phosphorylporphyrins. ${ }^{31,45,53}$ The meso-phenyl rings are twisted with respect to the porphyrin core by the following angles: 60.0 and $78.9^{\circ}$ for PdDTolPP, 85.6 and $63.7^{\circ}$ for PdD(CMP)PP, 84.3 and $63.7^{\circ}$ for PtD(CMP)PP.

In all three structures, solvent molecules are involved in intermolecular $\mathrm{C}-\mathrm{H} \cdots \mathrm{O}$ hydrogen bonds with phosphoryl oxygen atoms. In addition, we identified $\mathrm{Cl} \cdots \mathrm{O}$ and $\mathrm{Cl} \cdots \mathrm{C}$ contacts that are shorter than the sum of Bondi's van der Walls radii ${ }^{54}$ (Table S8, ESI).

The crystal packing for PdDTolPP. $\mathbf{C H}_{2} \mathbf{C l}_{2}, \quad \mathbf{P d D}(\mathbf{C M P}) \mathbf{P P} \cdot \mathbf{C H C l}_{3}$, and $\operatorname{PtD}(\mathbf{C M P}) \mathbf{P P} \cdot \mathbf{C H C l}_{3}$ is discussed in details in the ESI. It is formed mainly by interactions between porphyrin molecules (Figure S75, Table S9-10, ESI). However, such interactions should not play any role for photophysical measurements in solutions owing to the low porphyrin concentrations $\left(c<10^{-5} \mathrm{M}\right)$ used for these experiments.

\section{Photophysical properties}

The UV-vis absorption spectra of palladium(II) and platinum(II) complexes with the phosphorylated porphyrins $\mathbf{M R}^{1} \mathbf{P P}-\mathbf{M R}^{4} \mathbf{P P}$ (Fig. 2, Table 1 and Table S11 in the ESI) were measured in dilute toluene solutions at room temperature and compared to those of the respective complexes formed with the non-phosphorylated $\mathrm{A}_{2}$-type porphyrins $\mathbf{M R}^{\mathbf{1}} \mathbf{P}-\mathbf{M R}^{\mathbf{4}} \mathbf{P}$.

Changing aryl substituents from the electron-donating $p$-tolyl to the electron-accepting $p$-(carbomethoxy)phenyl group has only a little effect on the electronic spectra of the porphyrins. The spectrum of both Pd(II) complexes [PdDTolPP and PdD(CMP)PP] exhibit a Soret band 

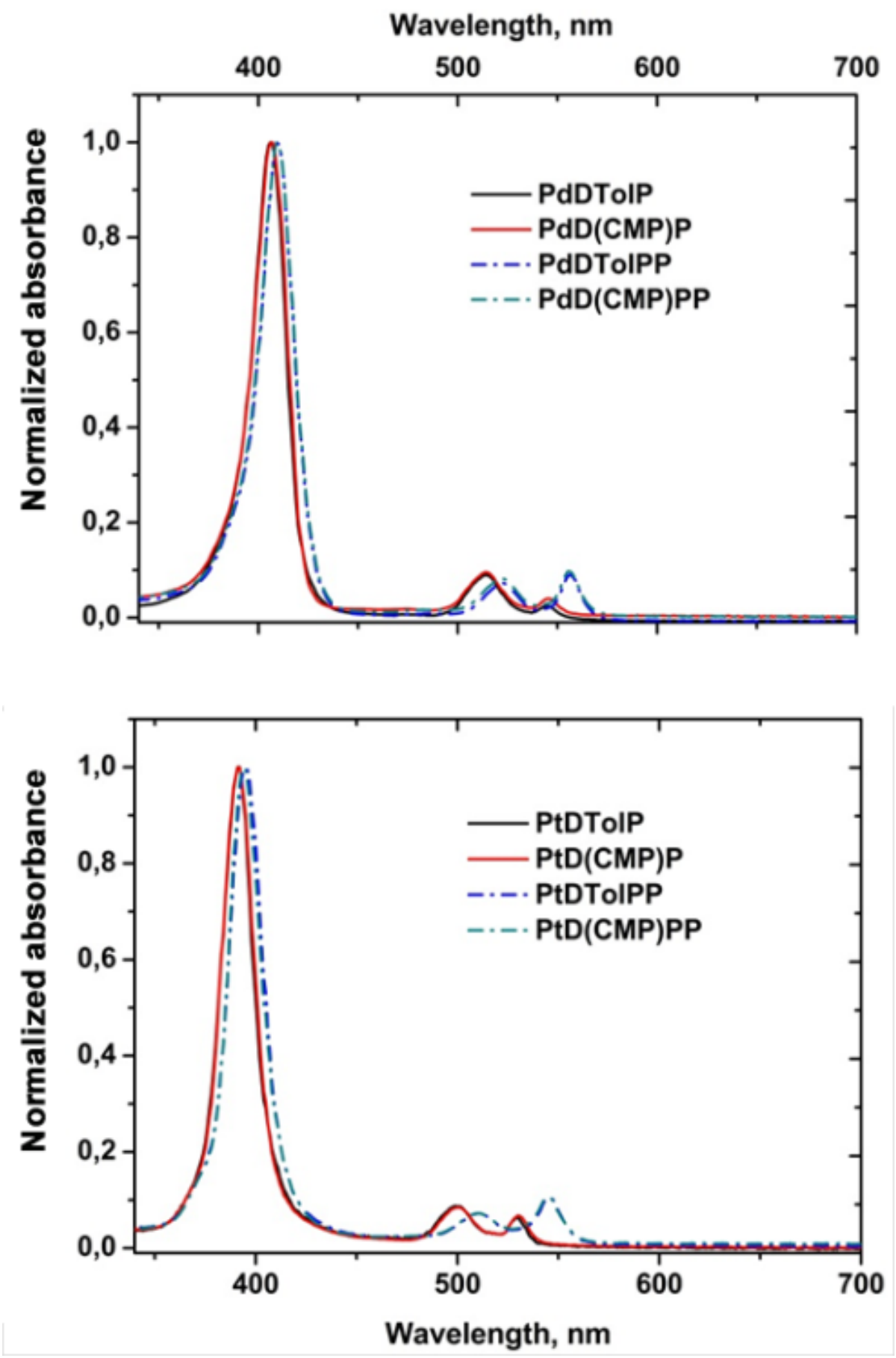

Fig. 2 UV-vis absorption spectra of the $\mathrm{Pd}(\mathrm{II})$ and $\mathrm{Pt}(\mathrm{II})$ phosphorylated $\mathbf{M R}^{\mathbf{1}} \mathbf{P P}-\mathbf{M R}^{4} \mathbf{P P}$ porphyrins and corresponding non-phosphorylated $\mathbf{M R}^{\mathbf{1}} \mathbf{P}-\mathbf{M} \mathbf{R}^{\mathbf{4}} \mathbf{P}$ counterparts in toluene.

at $409 \mathrm{~nm}$ and two $\mathrm{Q}(1,0)$ and $\mathrm{Q}(0,0)$ bands at 522 and $556 \mathrm{~nm}$, respectively. The absorption maxima of the corresponding platinum(II) complexes PtDTolPP and PtD(CMP)PP are hypsochromically shifted by $\sim 15 \mathrm{~nm}$ compared to those of the palladium(II) 
phosphorylporphyrins. The maximum of the Soret band of these complexes is located at 395 $\mathrm{nm}$, while that of the $\mathrm{Q}(1,0)$ and $\mathrm{Q}(0,0)$ bands is centred at 511 and $546 \mathrm{~nm}$, respectively.

Substitution in the meso-position of the porphyrin macrocycle with an electronwithdrawing phosphoryl group results in bathochromic shifts of all absorption maxima. Thus, the Soret band for the $\mathbf{M R}^{\mathbf{1}} \mathbf{P P}-\mathbf{M R}^{\mathbf{4}} \mathbf{P P}[\mathrm{M}=\mathrm{Pt}(\mathrm{II}), \mathrm{Pd}(\mathrm{II})]$ porphyrins was shifted by $3-5 \mathrm{~nm}$ and the $\mathrm{Q}$ bands by $\sim 8-15 \mathrm{~nm}$, in comparison with the corresponding $\mathbf{M R}^{1} \mathbf{P}-\mathbf{M R}^{4} \mathbf{P}$ complexes that have no phosphoryl group. The intensity of the $\mathrm{Q}(0,0)$ band for both $\mathrm{Pt}(\mathrm{II})$ and $\mathrm{Pd}(\mathrm{II})$ phosphorylated porphyrins is higher than that for the $\mathbf{M R}^{1} \mathbf{P}-\mathbf{M R}^{4} \mathbf{P}$ counterparts. This behavior can be explained by the Gouterman fourorbital model, ${ }^{55}$ namely that electron-withdrawing phosphoryl group at the mesoposition may increase the $a_{1 \mathrm{u}}-a_{2 \mathrm{u}}$ orbital energy spacing and thus the intensity of the $\mathrm{Q}(0,0)$ transition.

The $\mathrm{Pt}(\mathrm{II})$ and $\mathrm{Pd}(\mathrm{II})$ complexes with phosphorylated porphyrins $\mathbf{M R}^{\mathbf{1}} \mathbf{P} \mathbf{P}-\mathbf{M R}^{\mathbf{4}} \mathbf{P} \mathbf{P}$ show moderate phosphorescence in deoxygenated solution at room temperature; their photophysical data are listed in Table 1 and Table S11 (ESI). Fig. 3 shows representative examples of normalized excitation and emission spectra of the complexes under investigation [MR ${ }^{1} \mathbf{P P}$ and $\mathbf{M R}^{2} \mathbf{P P}$, with $\mathrm{M}=\mathrm{Pt}(\mathrm{II})$ and $\left.\mathrm{Pd}(\mathrm{II})\right]$ together with those corresponding to the reference compounds $\left[\mathbf{M R}^{\mathbf{1}} \mathbf{P}\right.$ and $\mathbf{M R}^{\mathbf{2}} \mathbf{P}$, with $\mathbf{M}=\operatorname{Pt}(\mathrm{II})$ and $\mathrm{Pd}(\mathrm{II})]$ in toluene at $298 \mathrm{~K}$. There is a close resemblance between the excitation and ground-state absorption spectra of all studied complexes. No fluorescence is detectable for the platinum(II) complexes and very little fluorescence $\left(\tau=3.75 \mathrm{~ns}, \phi_{\mathrm{F}}<0.1 \%\right)$ for the respective palladium(II) complexes. In general, the emission profile of phosphorylated $\mathrm{Pt}(\mathrm{II})$ and $\mathrm{Pd}(\mathrm{II})$ porphyrinates is nearly identical to that of nonphosphorylated derivatives, but as can be observed, the insertion of the electronwithdrawing phosphoryl group results in a bathochromic shift of the emission band by ca. 25-30 $\mathrm{nm}$ compared to the parent $\mathrm{A}_{2}$-type porphyrins. A narrow $\mathrm{Q}(0,0)$ emission band [full width at half-maximum intensity $(F W H M)=35 \mathrm{~nm}$ ] at $692 \mathrm{~nm}$ with a weak $\mathrm{Q}(1,0)$ band at $765 \mathrm{~nm}$ is observed for phosphorylated Pd(II) porphyrinates (Fig. 3a).

Absolute quantum yields ( $\left.\phi_{\mathrm{em}}\right)$ and luminescence lifetimes $(\tau)$ of the complexes were measured in deoxygenated toluene solutions. For the palladium(II) mesophosphorylporphyrins, the observed $\phi_{\mathrm{em}}$ and $\tau$ values are $4.3 \%$ and $640 \mu \mathrm{s}$ for PdDTolPP, 5.8\% and $633 \mu$ s for PdD(CMP)PP, 3.4\% and $770 \mu$ s for PdDMesPP, and 4.1\% and $858 \mu$ s for PdTMesPP. The corresponding platinum(II) complexes exhibit a 
hypsochromically shifted ( 20-25 $\mathrm{nm}$ ) [compared to $\mathrm{Pd}(\mathrm{II})$ porphyrinates] narrow $\mathrm{Q}(0,0)$ emission band $(\mathrm{FWHM}=30 \mathrm{~nm})$ at $670 \mathrm{~nm}$ with a weak $\mathrm{Q}(1,0)$ band at $739 \mathrm{~nm}$ (Fig. 3b). They also possess 2.5-3-fold higher luminescence quantum yields (9.2-11\%) and 10-fold lower luminescence decay times [65, 69, 64, and $56 \mu$ s for PtDTolPP, PtD(CMP)PP, PtDMesPP and PtTMesPP, respectively].

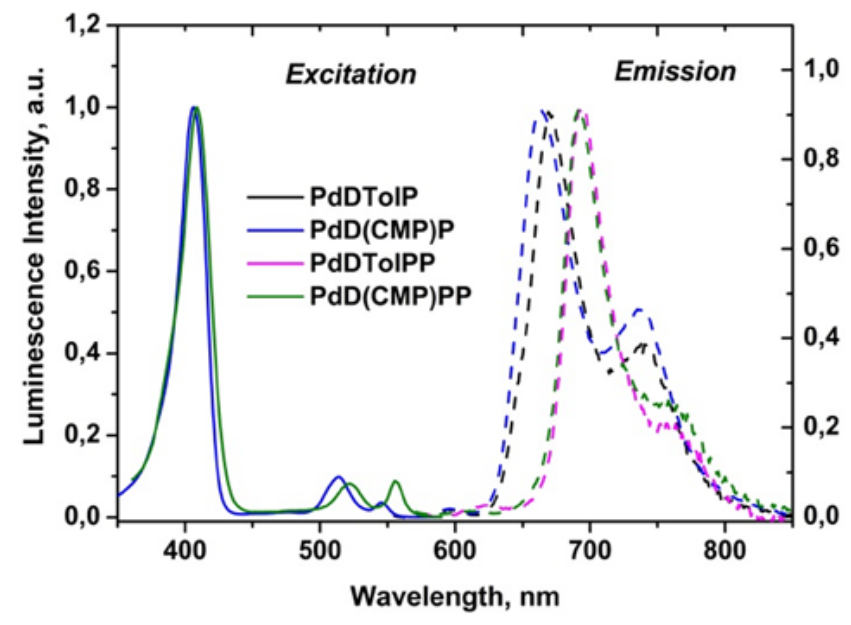

a)

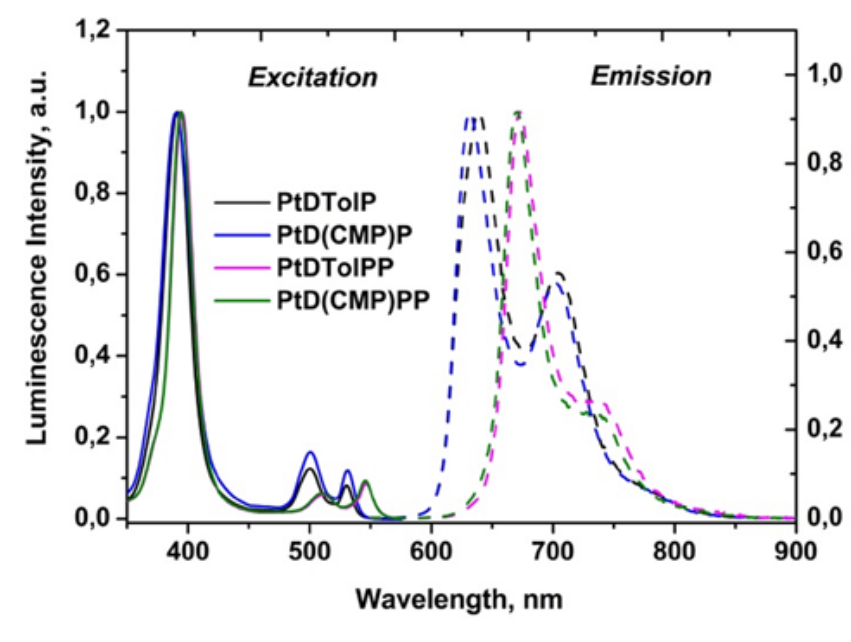

b)

Fig. 3 Excitation $\left[\mathrm{em}^{\mathrm{m}}=\max _{(\mathrm{nm})}\right]$ and emission $\left[\mathrm{ex}=\lambda_{\mathrm{abs}} \mathrm{Q}(1,0) \mathrm{nm}\right]$ spectra of the $\operatorname{Pd}(\mathrm{II})$ (a) and Pt(II) (b) complexes $\mathbf{M R}^{\mathbf{1}} \mathbf{P P}-\mathbf{M R}^{2} \mathbf{P P}$ in deoxygenated toluene at $298 \mathrm{~K}$. 
Furthermore, the emission spectra and decay times were recorded at $77 \mathrm{~K}$, because the data obtained at low temperature are more accurate than those at $298 \mathrm{~K}$ due to the absence of competing processes (Table 1; Fig. S76-77 and Table S11 in the ESI). At low-temperature, the ratio of the emission intensities for the red to NIR emission peaks is much smaller for the dyes without a phosphoryl group (especially in the case of platinum(II) complexes) than for the phosphorylated porphyrins. The obtained luminescence maxima at $77 \mathrm{~K}$ were used for estimation of the triplet excited-state energy $\left(E_{\mathrm{T}}\right)$, which are summarized in Table 1 and Table S11 (ESI). Introduction of the electron-withdrawing group leads to a decrease in energy of the triplet excited state, bringing the $E_{\mathrm{T}}$ values of the dye closer to the energy of the ${ }^{1} \Sigma_{g}^{+}$level of dioxygen $\left(E=13121 \mathrm{~cm}^{-1}\right) .{ }^{56}$ According to the data obtained at $77 \mathrm{~K}$, decay times of phosphorylated $\mathrm{Pt}(\mathrm{II})$ and $\mathrm{Pd}(\mathrm{II})$ complexes are slightly reduced with respect of those found for the corresponding $\mathbf{M} \mathbf{R}^{\mathbf{1}} \mathbf{P}-\mathbf{M R}^{4} \mathbf{P}$ diarylporphyrins. Among the phosphorylated complexes, the following trend is observed for the phosphorescence decay time $\tau$ at $77 \mathrm{~K}$ : MD(CMP)PP > MDTolPP > MDMesPP > MTMesPP. A similar tendency is observed in the case of the luminescence quantum yields determined at room temperature. Thus, the combination of electron-withdrawing phosphoryl and p-(carbomethoxy)phenyl substituents leads to the most favorable photophysical parameters. The phosphorylation of the porphyrin macrocycle results in reduction of both $\phi_{\mathrm{em}}$ and $\tau$, which can be explained by the increased probability of the nonradiative deactivation of the triplet excited state. However, the obtained values are consistent with those known for the most photostable palladium(II) and platinum(II) porphyrinates $\left(\mathbf{P t F}_{20}\right.$ TPP and $\mathbf{P d F}_{20}$ TPP), ${ }^{20,57}$ presented in the literature, so metalloporphyrins presented in this work are suitable for elaborating oxygen sensing devices.

Table 1. Photophysical properties of the phosphorylated $\mathbf{P t R}^{\mathbf{1}} \mathbf{P} \mathbf{P}-\mathbf{P t R}^{\mathbf{4}} \mathbf{P P}$ porphyrins and of the nonphosphorylated $\mathbf{P} \mathbf{t R}^{\mathbf{1}} \mathbf{P}-\mathbf{P t R}^{\mathbf{4}} \mathbf{P}$ counterparts in toluene

\begin{tabular}{|c|c|c|c|c|c|c|c|}
\hline Dye & $\begin{array}{l}\lambda_{\text {abs }}\left(\varepsilon \times 10^{-3}\right) \\
\left(\mathrm{nm}, \mathrm{M}^{-1} \mathrm{~cm}^{-1}\right)\end{array}$ & $\begin{array}{l}\lambda_{\mathrm{em}}{ }^{a} \\
(\mathrm{~nm})\end{array}$ & $\phi_{\mathrm{em}}{ }^{b}$ & $\begin{array}{l}\tau^{a} \\
(\mu \mathrm{s})\end{array}$ & $\begin{array}{l}\lambda_{\mathrm{em}}(77 \mathrm{~K})^{c} \\
(\mathrm{~nm})\end{array}$ & $\begin{array}{l}\tau(77 \mathrm{~K})^{c} \\
(\mu \mathrm{s})\end{array}$ & $\begin{array}{l}E_{\mathrm{T}}^{d} \\
\left(\mathrm{~cm}^{-1}\right)\end{array}$ \\
\hline PtTMesPP & $402(136), 515(12), 549(9)$ & 674 & 11 & 56 & 666,741 & 94 & 15020 \\
\hline PtDMesPP & $394(211), 510(13), 545(21)$ & 670 & 9.2 & 64 & 662,734 & 117 & 15100 \\
\hline PtDTolPP & $396(257), 511(17), 546(26)$ & 672,740 (sh.) & 11 & 65 & 663,737 & 119 & 15080 \\
\hline PtD(CMP)PP & $395(325), 510(28), 546(41)$ & 671,740 (sh.) & 11 & 69 & 660,735 & 122 & 15150 \\
\hline PtTMesP & $397(184), 506(18), 536(9)$ & 650 & 9.3 & 83 & 643,712 & 122 & 15550 \\
\hline PtDMesP & $391(241), 501(19), 532(16)$ & 637 & 13 & 82 & 633,701 & $122^{e}$ & 15800 \\
\hline PtDTolP & $393(143), 500(24), 529(18)$ & 639,705 (sh.) & 15 & 87 & 635,703 & 133 & 15748 \\
\hline PtD(CMP)P & $392(206), 502(18), 531(14)$ & 632,702 (sh.) & 16 & 82 & 634,700 & 137 & 15773 \\
\hline $\mathbf{P t F}_{20} \mathbf{T P P}^{f}$ & $390(323), 504(23), 538(29)$ & $647,710(\mathrm{sh})$ & 8.8 & 60 & - & - & - \\
\hline
\end{tabular}

${ }^{a}$ Measured in diluted toluene solutions at $298 \mathrm{~K}$ deoxygenated by nitrogen bubbling. ${ }^{b}$ The absolute emission quantum yields were determined with an integrating sphere. ${ }^{c}$ Measured in frozen glasses (toluene/tetrahydrofuran $4: 6 \mathrm{v} / \mathrm{v}) .{ }^{d}$ Calculated from the emission spectra at $77 \mathrm{~K}$. ${ }^{e}$ Non mono-exponential signal with a much longer component $(1.56 \mathrm{~ms})$ is present. ${ }^{\mathrm{f}}$ Data in $\mathrm{CH} 2 \mathrm{Cl} 2$ are taken from ref. ${ }^{20}$ 


\section{Quenching by molecular oxygen in solution}

Phosphorescence of all the investigated complexes is effectively quenched in solution by molecular oxygen. Studies were conducted with PdDTolPP, PdD(CMP)PP, PtDTolPP, PtD(CMP)PP and their non-phosphorylated counterparts. The results are presented in Fig. 4 and Fig. S78 (ESI). However, the $\operatorname{Pd}(\mathrm{II})$ complexes show significantly lower luminescence brightness and very high sensitivity even at low dioxygen partial pressure in solution $\left(\mathrm{pO}_{2}\right)$, making precise measurements challenging. Thus, the oxygen quenching processes in solution were investigated in detail only for the phosphorylated PtDTolPP and PtD(CMP)PP porphyrins, and for the corresponding non-phosphorylated PtDTolP and PtD(CMP)P counterparts.

The dioxygen quenching of phosphorescence intensity (Fig. 4a) and decay time (Fig. 4b) can be interpreted in terms of the Stern-Volmer relation, $I_{0} / I=\tau_{0} / \tau=1+k_{\mathrm{q}} \quad{ }_{0}\left[\mathrm{O}_{2}\right]$ $=1+K_{\mathrm{sv}} \mathrm{pO}_{2}$, where $I_{0}$ and $I$ denote the phosphorescence intensity in the absence and the presence of dioxygen, respectively; $\tau_{0}$ and $\tau$ correspond to the related decay lifetimes, $k_{\mathrm{q}}$ is the bimolecular quenching constant; $K_{\mathrm{sv}}$ is the Stern-Volmer constant.

As expected, all the studied complexes show good linearity of $\tau_{0} / \tau$ as a function of $\mathrm{pO}_{2}$ between 0 and $1.95 \mathrm{kPa}$, which indicates an effective homogeneous oxygen quenching in solution. The calculated $K_{\mathrm{SV}}$ values for both platinum(II) phosphorylated porphyrins PtDTolPP and PtD(CMP)PP are similar $\left[10.42 \mathrm{kPa}^{-1}\right.$ for PtDTolPP and $10.53 \mathrm{kPa}^{-1}$ for PtD(CMP)PP], but lower than the corresponding $K_{\mathrm{SV}}$ values for the Pt(II) complexes lacking the phosphoryl group $\left[15.08 \mathrm{kPa}^{-1}\right.$ for PtDTolP and $12.36 \mathrm{kPa}^{-}$

${ }^{1}$ for PtD(CMP)P]. This is mostly due to the longer decay times of the latter. On the other hand, the bimolecular quenching constants $k_{\mathrm{q}}=K_{\mathrm{SV}} / \tau_{0}$ are also slightly smaller in the case of phosphorylated complexes $\left[k_{\mathrm{q}}=173,160,156,153 \mathrm{~Pa}^{-1} \mathrm{~s}^{-1}\right.$ for PtDTolP, PtD(CMP)P, PtDTolPP, and PtD(CMP)PP, respectively]. This may be due to the slow diffusion rates in solution of the bulky phosphorylated porphyrins, or to the proximity of the $E_{\mathrm{T}}$ value of the dyes with the ${ }^{1} \Sigma_{g}^{+}$energy level of dioxygen. Nevertheless, the sensitivity of the platinum(II) phosphorylated porphyrin complexes is comparable to that of the commonly used PtOEP (210 $\mathrm{Pa}^{-1} \mathrm{~s}^{-1}$ in toluene). ${ }^{25}$ Thus, it can be concluded that these dyes and their derivatives are suitable indicators for developing optical oxygen sensors. 


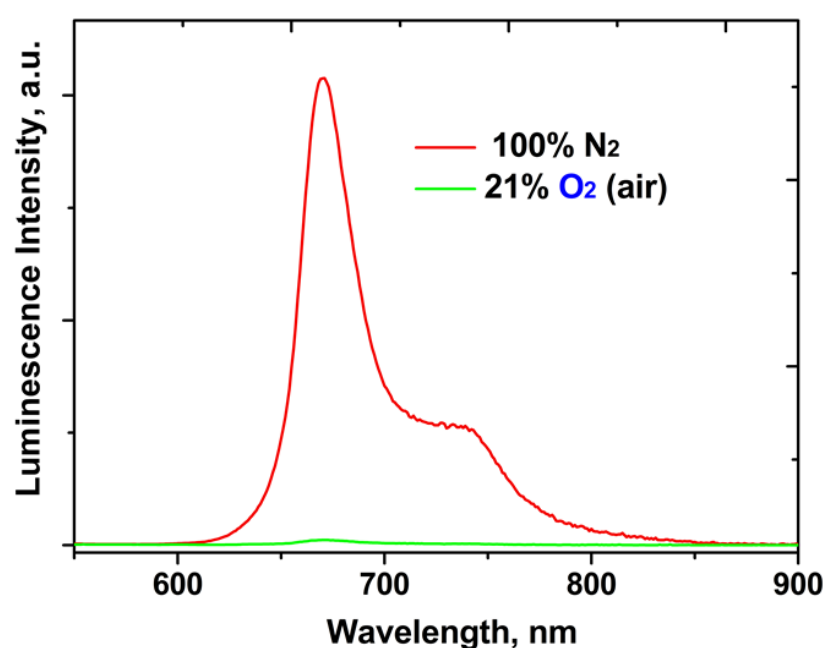

a)

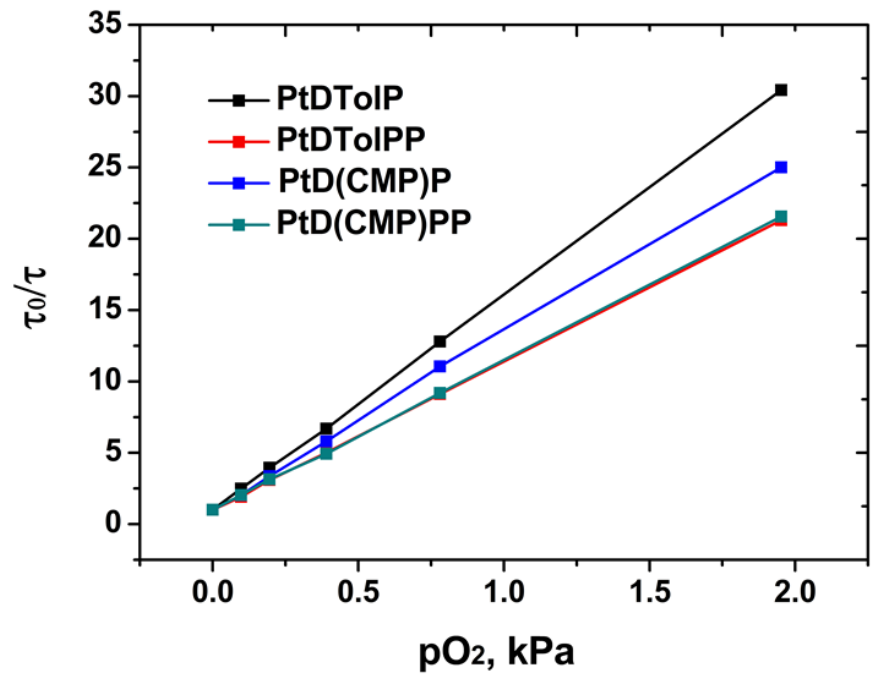

b)

Fig. 4. Luminescence spectra of PtDTolPP in toluene at $298 \mathrm{~K}$ in the absence and in the presence of dioxygen $\left(\lambda_{\text {ex }}=511\right.$ nm) (a); Stern-Volmer plots for $\mathbf{P t R}^{\mathbf{1}}, \mathbf{R}^{\mathbf{2}} \mathbf{P}$ and $\mathbf{P t R}^{\mathbf{1}}, \mathbf{R}^{\mathbf{2}} \mathbf{P P}$ in toluene $\left(\sim 7 \mathrm{x} 10^{-6} \mathrm{M}, 295 \mathrm{~K}\right)(\mathrm{b})$.

\section{Photostability}

Increasing interest in the development of oxygen sensors ${ }^{10,58}$ and imaging agents, ${ }^{7,8}$ which should be stable under different environmental conditions and useful for measurements in biosamples and in vivo, explains the particular attention paid on improving their photostability. ${ }^{59-61}$ While the photoinduced degradation pathways of many organic fluorophores, such as coumarins, rhodamines, and cyanines, have been explored to some extent, ${ }^{13}$ the reactions involved in the photobleaching of porphyrins and phthalocyanines are less well understood. Various porphyrins have been considered as potential dioxygen sensors, ${ }^{41,62-67}$ and for some of the series the influence of their peripheral substituents on the efficiency of $\mathrm{O}_{2}$ detection has been investigated. ${ }^{20,22,49,68}$ However, discussions of their photostability are commonly limited to a general 
statement that the introduction of electron-withdrawing substituents at the tetrapyrrolic macrocycle or at peripheral aryl groups increases the photostability, as typically observed for other organic fluorophores. ${ }^{8,20,22}$ To the best of our knowledge, mechanisms of the photoinduced degradation of porphyrins in solution have still not been reported and data accumulated for photobleaching of phthalocyanines ${ }^{69}$ are also insufficient for suggesting any general reaction pathway.

In this work, we compared the photostability of different porphyrinylphosphonate diesters (MR $\left.{ }^{1} \mathbf{P P}-\mathbf{M R}^{\mathbf{4}} \mathbf{P P}\right)$ and analogous compounds $\left(\mathbf{M R}^{\mathbf{1}} \mathbf{P}-\mathbf{M R}^{\mathbf{4}} \mathbf{P}\right)$ that lack the phosphorous substituent, to get a deeper insight on the influence of peripheral substituents at the tetrapyrrolic macrocycle on the photostability of porphyrins.

The photodegradation of all platinum(II) and palladium(II) complexes was studied at first in DMF under the same conditions. The porphyrin solutions $(c=5 \mu \mathrm{M})$ were irradiated at $25{ }^{\circ} \mathrm{C}$ in air using a $400 \mathrm{~W}$ lamp, which emits in the visible and IR range (350-800 nm; Figure S79, ESI). The photoinduced degradation kinetics of each tested compound was monitored by absorption spectrophotometry at the maximum of the Soret band until nearly or complete disappearance. The electronic absorption spectrum of the resulting solution was recorded at the end of the irradiation period. In all cases, the final solution did not absorb visible light anymore. No further efforts to identify the products were undertaken.

Although we have followed a commonly used methodology for studying the photobleaching of organic compounds, ${ }^{70}$ it should be stressed that these experiments allow only a semi-quantitative comparison within a defined series of analogous chromophores. Indeed, the degradation rate depends, among other factors, on the concentration of the chromophore, the photon absorption cross section, the intersystem crossing efficiency, and the triplet state lifetime. For comparison purposes, the concentration and the total amount of absorbed photons should be identical for all investigated substances, which is in practice an unachievable situation as the light absorptivity $\left(\int \mathcal{E}(\lambda) \mathrm{d} \lambda\right)$ of even closely structurally related molecules might significantly vary with the nature of peripheral substituents born by the aromatic moiety.

The time course of the normalized absorbance decay recorded over more than $80 \mathrm{~h}$ of continuous irradiation for seven platinum porphyrinylphosphonate diesters is depicted in Fig. 5. The inset of Fig. 5 clearly shows an induction period during which the absorbance remains nearly constant over about 25-35 min, followed by an abrupt multiphasic decrease associated to photobleaching. The systematic observation of an 


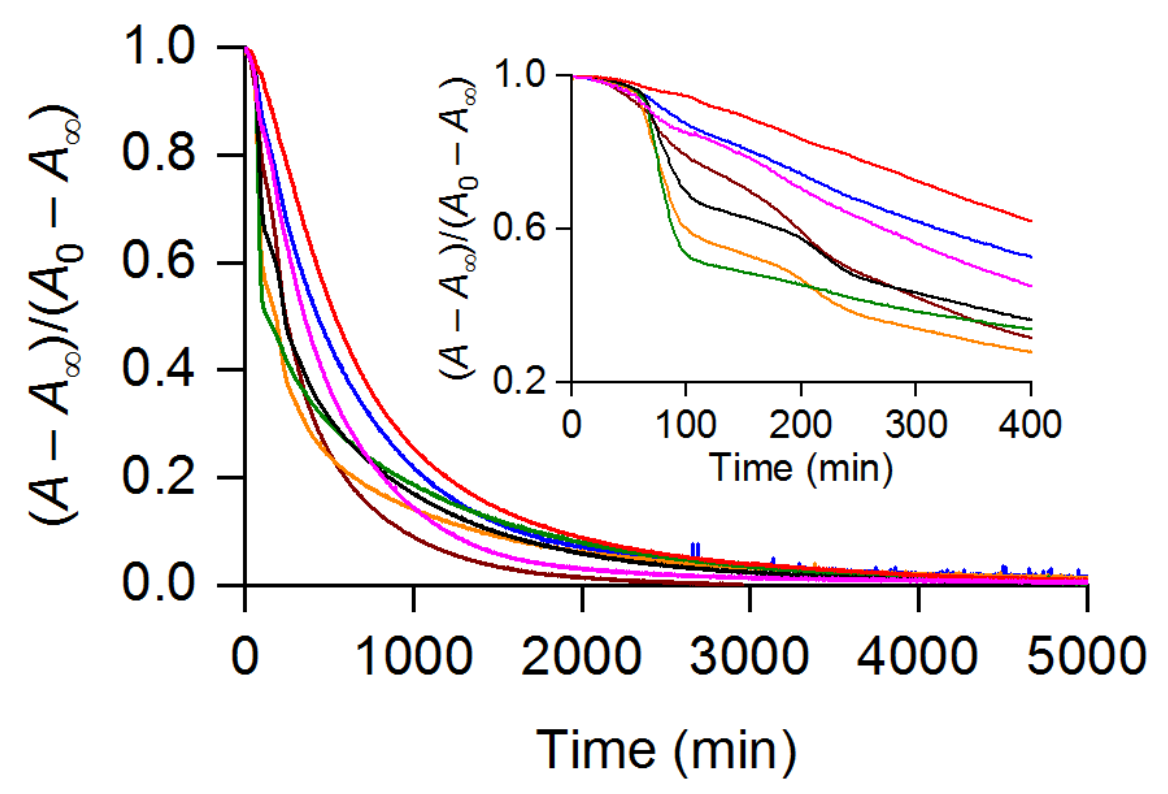

Fig. 5. Photodegradation of platinum porphyrins $(c=5 \mu \mathrm{M})$ in DMF at $25.0(5){ }^{\circ} \mathrm{C}$ under vis-NIR irradiation with an Osram Powerstat HQI BT $400 \mathrm{~W}$ lamp. Colour code: PtDTolP (brown), PtDTolPP (orange), PtD(CMP)PP (green), PtDMesP (magenta), PtDMesPP (black), PtTMesP (blue), PtTMesPP (red).

initiation phase strongly supports the photoinduced build-up of radicals, which are presumably responsible for different degradation processes occurring consecutively or simultaneously as suggested by the non-monotonous decay curves of several studied compounds.

As shown in Fig. 5, the rate of the porphyrin photobleaching depends strongly on the substituents attached at the periphery of the tetrapyrrolic core. For example, the extend of degradation during the first $100 \mathrm{~min}$ of irradiation varies from 5 to $45 \%$, depending on the porphyrin structure. Moreover, the number and nature of peripheral substituents have a most significant influence on the peculiar shape of the kinetic traces. Accordingly, the compounds studied herein can be divided into two sets. The first group is formed by the mesityl-substituted porphyrins PtDMesP, PtTMesP, and PtTMesPP, which are decomposed according to one predominant pathway, like most of the previously studied organic phosphores. ${ }^{13,70}$

The absorbance decline can be approximated by a single exponential decay function. Moreover, no noticeable band shift could be detected over time when the degradation of PtTMesPP was monitored over the entire 350-600 nm range (Fig. S80, ESI). The photobleaching rates of these compounds can be compared by considering the pseudofirst-order rate constants summarized in Table 2 derived by nonlinear least squares 
adjustment of the experimental data after cutting the induction period (Fig. S83-S85, ESI).

Table 2. Pseudo-first-order rate constants $\left(k_{\mathrm{obs}}\right)$ for the photodegradation of platinum porphyrins in DMF a $25.0(5){ }^{\circ} \mathrm{C}$

\begin{tabular}{lll}
\hline Compound & $k_{\text {obs }}\left(\mathrm{s}^{-1}\right)$ & $k_{\text {obs }} / k_{\text {obs }}($ PtDMesP $)$ \\
\hline PtDMesP & $3.66 \times 10^{-5}$ & 1 \\
PtTMesP & $2.83 \times 10^{-5}$ & 0.77 \\
PtTMesPP & $2.66 \times 10^{-5}$ & 0.73 \\
\hline
\end{tabular}

The introduction of a third mesityl substituent at the meso position of the macrocycle increases the photostability of platinum 5,15-dimesitylporphyrinate (PtDMesP), as PtTMesP decomposes 1.3-fold more slowly than PtDMesP. Comparison of the photobleaching rate constants of PtTMesP and PtTMesPP reveals that the introduction of the diethoxyphosphoryl group at meso position of the macrocycle improves the photostability of the porphyrin only slightly, in spite of the strong electron-withdrawing character of this group.

All the other platinum porphyrinates [PtDMesPP, PtDTolP, PtDTolPP, and PtD(CMP)PP] belong to the second group of studied complexes, for which the intricate decomposition kinetics proceeds according to several pathways, as highlighted by a first slowdown of the degradation rate some minutes only after the initial boost, which is followed by a second boost before the final rate deceleration. In addition, the degradation of PtDTolPP was also monitored over the entire 350-600 $\mathrm{nm}$ range (Fig. S81, ESI). Although no noticeable band shift could be detected during the first $40 \mathrm{~h}$ of irradiation $\left(\lambda_{\mathrm{abs}}=395,511\right.$, and $\left.546 \mathrm{~nm}\right)$, the Soret band undergoes a slight bathochromic shift of ca. $7 \mathrm{~nm}$ during the final stage of the degradation $(40-116 \mathrm{~h})$. This particular succession of fast and slow regimes hampers a quantitative analysis. All compounds belonging to this second category are less stable than those of the first series, even if the electronwithdrawing diethoxyphosphoryl substituent is present at the periphery of the macrocycle. Regarding the kinetics of decomposition of PtDMesPP, PtDTolPP, and PtD(CMP)PP, we can note that the replacement of both mesityl substituents by $p$ methylphenyl or $p$-methoxycarbonylphenyl groups accelerates photobleaching. Also, the introduction of the phosphorous substituent on PtDMesP and PtDTolP has negative influence on the porphyrin degradation, at least in the early stage of the process. Considering the electronic effects of all these substituents, it can be concluded that the electron-withdrawing character does not always increase the photostability in this series 
of porphyrins, as claimed earlier for porphyrins bearing pentafluorophenyl or other strongly electron-withdrawing substituents. ${ }^{1,8}$

Interestingly, the introduction of a diethoxyphosphoryl group can change the photodegradation pathways in DMF, as clearly revealed by the comparison of the bleaching curves of PtDMesP and PtDMesPP. While the degradation of PtDMesP can be considered in first approximation as a pseudo-first order process, the decomposition of the phosphorylated derivative involves several pathways. This might be reasonably explained by the reactivity of the meso site at which a bulky diethoxyphosphoryl group is attached. We have already reported on the unusual $\mathrm{C}-\mathrm{P}$ bond cleavage undergone by porphyrinylphosphonate diesters under acidic conditions. ${ }^{30,45}$ It seems that irradiation also accelerates the cleavage of $\mathrm{C}-\mathrm{P}$ bond.

Another conclusion is that the compounds bearing mesityl groups are the most stable ones, while an increasing number of hydrogen atoms in either meso and/or in ortho positions of meso aryl substituents accelerates the degradation of platinum porphyrinates. These less stable macrocycles are decomposed according to several pathways, presumably because these meso and ortho hydrogen atoms take part in photoinduced redox processes upon irradiation.

Next, the photostability of the PdD(CMP)PP, PdDMesPP, PdTMesP, PdTMesPP palladium complexes and of the reference compound $\mathbf{P d F} \mathbf{d F}_{\mathbf{2 0}} \mathbf{T P P}$ was investigated under the same conditions. The results are summarized in Fig. 6 and compared to those of the corresponding platinum complexes in Fig. S82 (ESI). For a given substitution pattern, the palladium porphyrin is significantly less stable than the platinum counterpart. Within the palladium series, the trimesitylphosphorylporphyrin PdTMesPP displays a higher photostability compared to that of dimesityl- (PdDMesPP) and $\operatorname{bis}[(p$ methoxycarbonyl)phenyl] PdD(CMP)PP phosphorylporphyrins. Surprisingly, PdF 20 TPP, known for its high photostability, ${ }^{1,8}$ was significantly more reactive than the mesityl-substituted derivatives under the conditions employed in this work. 


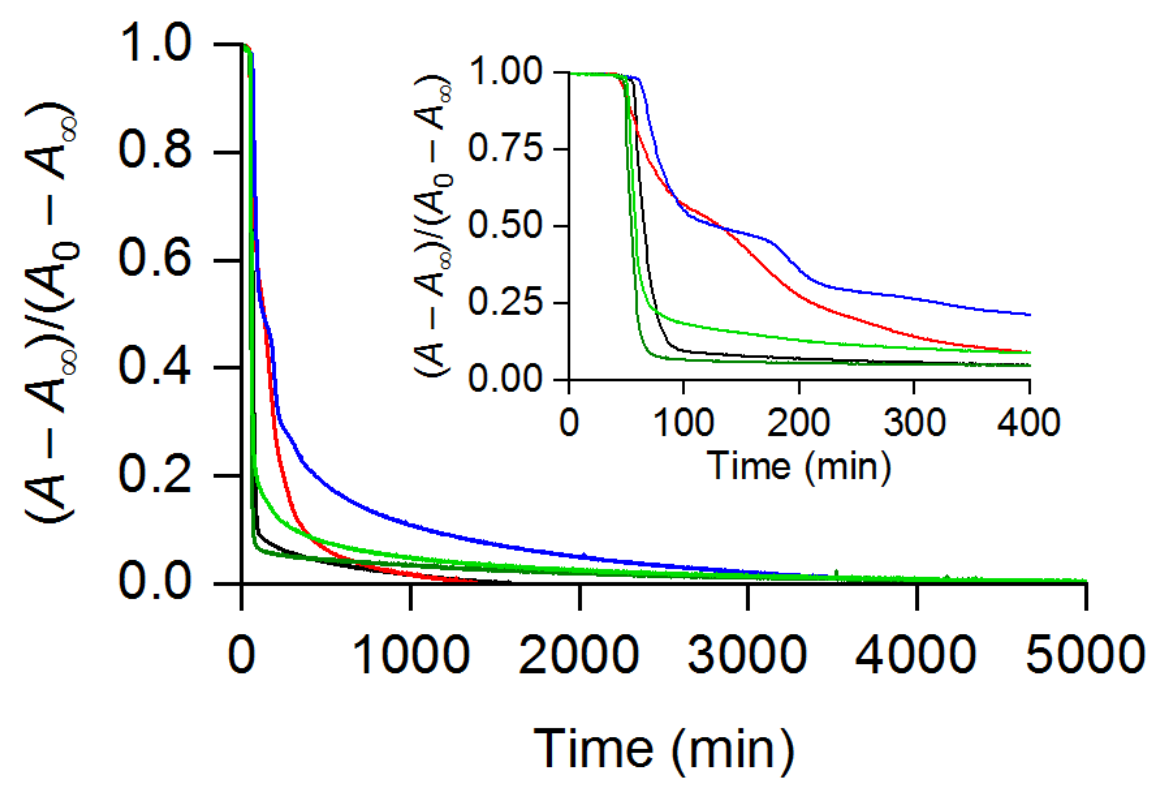

Fig. 6. Photodegradation of platinum porphyrins $(c=5 \quad \mathrm{M})$ in $\mathrm{DMF}$ at $25.0(5)^{\circ} \mathrm{C}$ under vis-NIR irradiation with an Osram Powerstar HQI BT $400 \mathrm{~W}$ lamp. Colour code: PdD(CMP)PP (dark green), PdDMesPP (black), PdTMesP (blue), PdTMesPP (red), PdF 20 TPP (green).

Next, the photodegradation kinetics of the most stable palladium complexes PdTMesPP and PdDMesPP, together with the platinum porphyrin PtTMesP were also investigated in toluene under identical irradiation conditions. In these experiments, the porphyrin concentrations slightly varied $(4.3-5.2 \mu \mathrm{M})$ because the initial absorbance at the maximum of the Soret band was fixed to $A=1.0$ (Fig. 7).

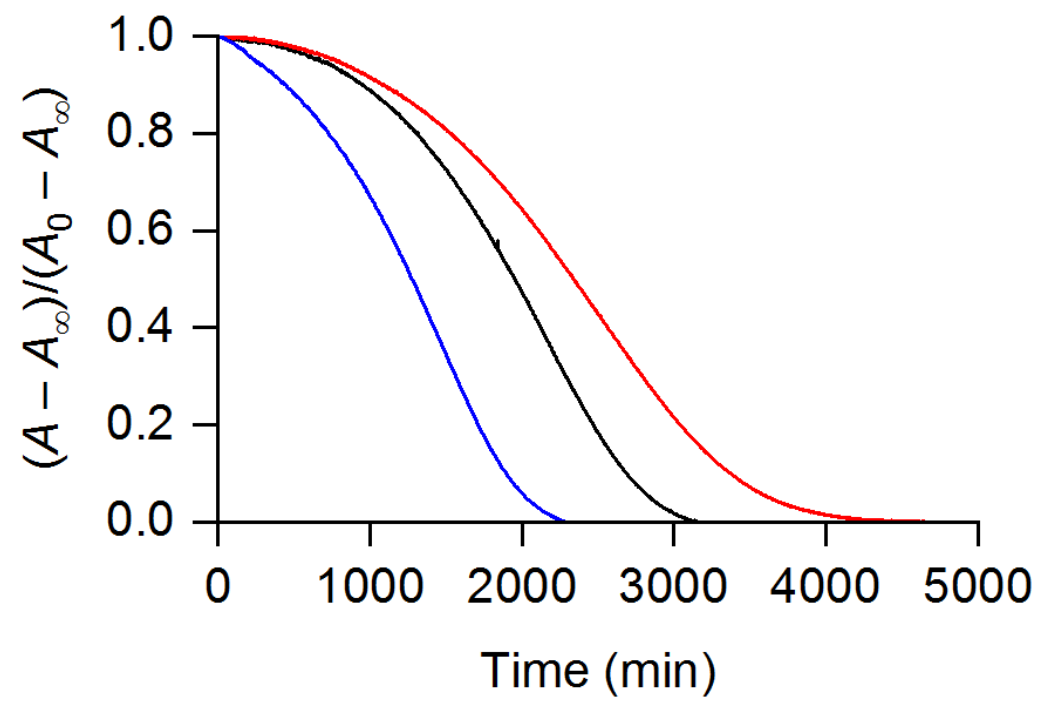

Fig. 7. Photodegradation of PdDMesPP ( $c=4.6 \mu \mathrm{M}$, black), PdTMesPP ( $c=4.3 \mu \mathrm{M}$, red), and PtTMesP $(c$ $=5.2 \mu \mathrm{M}$, blue) in toluene at $25.0(5)^{\circ} \mathrm{C}$ under vis-NIR irradiation with an Osram Powerstar HQI BT $400 \mathrm{~W}$ lamp. 
Absorbance decay curves of nearly sigmoidal shapes were observed, presumably because of the occurrence of side reactions involving photooxidation products of toluene and palladium phosphrorylporphyrins. Nevertheless, it has been noted that the trimesityl-substituted derivative PdTMesPP resists better to photobleaching in toluene compared to PdDMesPP, in agreement with the results obtained in DMF. Remarkably, the platinum complex PtTMesP exhibit higher reactivity in toluene than the two other investigated palladium porphyrins, whereas the reverse trend was observed in DMF.

Finally, the photostability of four palladium(II) [PdDTolP, PdDTolPP, PdD(CMP)PP, and PdTPP (TPP = 5,10,15,20-tetraphenylporphyrin)] (Fig. S86, ESI) and two platinum(II) complexes [PtDTolPP and PtD(CMP)PP] (Fig. S87, ESI) was investigated in air-saturated toluene solutions stored under day light during 2 months. It was observed that the platinum(II) derivatives PtDTolPP and PtD(CMP)PP are less stable compared to their palladium(II) counterparts [PdDTolPP and $\mathbf{P d D}(\mathbf{C M P}) \mathbf{P P}]$, in accordance with the aforementioned investigations performed in the same solvent. Concomitantly to the absorbance decrease, new absorption bands in the case of platinum(II) phosphorylated porphyrinates were observed at higher wavelengths after two months of exposure to sunlight. Moreover, the phosphorylated derivatives PdDTolPP and PdD(CMP)PP degraded more slowly (25-35\%) than PdDTolP and PdTPP (75-90\%). So, under these conditions the introduction of the electron-withdrawing phosphoryl group in the palladium(II) porphyrins seems to increase their photostability, as it was observed for PtTMesP and PtTMesPP in DMF.

It turns out that the photobleaching rate of phosphrorylporphyrins is highly solvent dependent. Likewise, the central metal atom plays a crucial role, palladium complexes being more reactive than platinum ones in DMF, why the trend is reversed in toluene. Not surprisingly, the number and nature of meso substituents have also a significant impact on the degradation pathways and rates. Peripheral aromatic groups with ortho hydrogen atoms are less protective than those possessing methyl groups (e.g. mesityl) at the same position. Among the series of compounds considered in this work, the trimesitylporphyrinylphosphonate diesters PdTMesPP and PtTMesPP exhibit the highest photostability in air-saturated DMF solution and toluene. Thus, they are presumably the most appealing phosphorylated derivatives for dioxygen sensing in biological samples or covalent immobilization on solid supports to prepare sensing devices, including optical fibers.

\section{Conclusions}


In conclusion, $\mathrm{Pd}(\mathrm{II})$ and $\mathrm{Pt}(\mathrm{II})$ complexes with electron-deficient meso(diethoxyphosphoryl)porphyrins have been conveniently prepared and characterized. The complexes under investigation emit at room temperature in the near-infrared region (670-770 nm). Absorption and emission spectrophotometric studies indicate that the incorporation of diethoxyphosphoryl group at the meso positions of the porphyrin ring results in bathochromic shifts of the absorption $(\sim 5 \mathrm{~nm}$ for Soret band and $\sim 15 \mathrm{~nm}$ for $\mathrm{Q}$ bands) and the emission ( $25-30 \mathrm{~nm})$ bands of complexes compared to those of the parent $\mathrm{A}_{2}$-type porphyrins. Phosphorescence quantum yields of the palladium(II) mesophosphorylated porphyrins lie in the range of 3.4 to $5.8 \%$, with lifetimes of 633 to 858 $\mu \mathrm{s}$ in deoxygenated toluene solutions at room temperature. The corresponding platinum(II) complexes exhibit quantum yields in the range of 9.2 to $11 \%$, with luminescence decay time constants of 56 to $69 \mu \mathrm{s}$. The obtained values are consistent with those known for the most photostable palladium(II) and platinum(II) porphyrinates $\left(\mathbf{P t F}_{20}\right.$ TPP and PdF 20 TPP) reported so far. Luminescent oxygen sensing properties of the $\mathrm{Pt}(\mathrm{II})$ complexes were studied in solution. Our results demonstrate effective homogeneous oxygen quenching and good sensitivities, with bimolecular quenching constants $\left(k_{\mathrm{q}}\right)$ of $\sim 155 \mathrm{~Pa}^{-1} \mathrm{~s}^{-1}$ in toluene for the platinum(II) phosphorylated porphyrinates. It was also observed that the photostability of porphyrinylphosphonates strongly depends on both the solvent and the substituents occurring at the periphery of the macrocycle. Among the studied compounds, platinum(II) and palladium(II) trimesitylphosphrorylporphyrins PdTMesPP and PtTMesPP exhibit a high photostability in air-saturated DMF solution. Thus, phosphorylated metalloporphyrins presented in this work are suitable for preparing dioxygen-sensing devices.

\section{Experimental section}

\section{General methods and characterization of compounds}

Unless otherwise noted, all chemicals and starting materials were obtained commercially from $A \operatorname{cros}{ }^{\circledR}$ or $A l d r i c h \AA$, and used without further purification. Solvents were dried using standard procedures. ${ }^{71}$ Chloroform (analytical grade) was purchased from Merck and was distilled over $\mathrm{CaH}_{2}$. DMA was dried over molecular sieves. Toluene (HPLCgrade) was dried over alumina cartridges using the solvent purification system PureSolv PS-MD-5 model from Innovative Technology. Analytical thin-layer chromatography 
(TLC) was carried out using Merck silica gel 60 plates (precoated sheets, $0.2 \mathrm{~mm}$ thick, with the fluorescence indicator F254). Column chromatography purifications were carried out on silica gel (MN Kieselgel 60, 63-200 $\mu \mathrm{m}$, Macherey-Nagel or Silica 60, 63-200 m, Aldrich). Gel permeation chromatography was carried out using BioBeads ${ }^{\mathrm{TM}} \mathrm{S}-\mathrm{X} 3$ Support (Bio-Rad Laboratories). ${ }^{1} \mathrm{H},{ }^{13} \mathrm{C}$, and ${ }^{31} \mathrm{P}$ NMR spectra were acquired on Bruker Avance III (600 MHz), Avance III (500 MHz), or Avance II (300 $\mathrm{MHz}$ ) spectrometers. Chemical shifts are expressed in parts per million (ppm), referenced on the $\delta$ scale by using residual non-deuterated solvent signals as internal standard for ${ }^{1} \mathrm{H}$ and ${ }^{13} \mathrm{C}$ NMR spectroscopies and external phosphoric acid $\left(\mathrm{H}_{3} \mathrm{PO}_{4}\right)$ for ${ }^{31} \mathrm{P}$ NMR spectroscopy. The coupling constants are expressed in units of frequency $(\mathrm{Hz})$. MALDI-TOF mass-spectra were obtained on a Bruker Ultraflex II LRF 2000 massspectrometer in positive ion mode with a dithranol matrix. Accurate mass measurements (HRMS) were recorded on a Thermo LTQ Orbitrap XL apparatus equipped with electrospray ionization (ESI) source. Solutions in $\mathrm{CHCl}_{3} /$ methanol $(1: 1)$ were used for the analysis. The reported $\mathrm{m} / \mathrm{z}$ values correspond to the most intense peak of the isotopic pattern that were simulated with the Xcalibur software (Thermo). FT-IR spectra were collected at $4 \mathrm{~cm}^{-1}$ resolution on either a FT-IR Nexus (Nicolet) or a Vertex 70v (Bruker) spectrometer equipped with an universal micro-ATR (Pike) or an A225 (Bruker) ATR sampling accessory, respectively. The UV-vis spectra were recorded with a Helios Alpha (Thermo Electron), CARY 50(Varian), CARY 5000 (Varian) and a Shimadzu 2450 spectrophotometers by using rectangular quartz cells $(1-10 \mathrm{~mm})$.

The measurements were performed at the Shared Facility Centers of the Institute of Physical Chemistry and Electrochemistry, RAS, and at the "Plateforme d'Analyses Chimiques et de Synthèse Moléculaire de l'Université de Bourgogne - Pôle Chimie Moléculaire", the technological platform for chemical analysis and molecular synthesis (http://www.wpcm.fr).

\section{X-ray crystallography}

Single crystals of PdDTolPP. $\mathbf{C H}_{2} \mathbf{C l}_{2}$ were obtained by slow diffusion of $n$-hexane into a solution of the $\mathrm{Pd}(\mathrm{II})$ complex in dichloromethane. Single crystals of PdD(CMP)PP. $\mathbf{C H C l}_{3}$ and PtD(CMP)PP. $\mathbf{C H C l}_{3}$ were grown by slow diffusion of $n$ hexane into solutions of the corresponding $\mathrm{Pd}(\mathrm{II})$ and $\mathrm{Pt}(\mathrm{II})$ complexes in chloroform. Crystals mounted onto a glass needle using silica oil, were cooled to the data collection 
temperature of $100 \mathrm{~K}$. X-ray diffraction experiments for single crystals were performed on a Bruker Kappa Apex II automatic four-circle diffractometer equipped with an area detector (Mo $\mathrm{K}_{\alpha}$ sealed-tube X-ray source, $\lambda=0.71073 \AA$, graphite monochromator). The unit cell parameters were refined over whole dataset using SAINT-Plus. ${ }^{72}$ The experimental reflection intensities were corrected for absorption using the SADABS program. ${ }^{73}$ The structures were solved with the ShelXT ${ }^{74}$ program and refined by the full-matrix least-squares method (SHELXL-2014 ${ }^{75}$ ) on $F^{2}$ over the whole dataset in the anisotropic approximation for all nonhydrogen atoms, both routines being implemented in the Olex 2 environment. ${ }^{76}$ The $\mathrm{H}$ atoms were placed in the geometrically calculated positions with the isotropic temperature factors set at 1.2 times ( $\mathrm{CH}$ groups) or 1.5 times $\left(\mathrm{CH}_{3}\right.$ group) the equivalent isotropic temperature factor of their bonded $\mathrm{C}$ atoms. Table S1 (ESI) lists the crystallographic characteristics and details of the diffraction experiments.

X-ray diffraction experiments were performed at the Center for Shared Use of Physical Methods of Investigation at the Frumkin Institute of Physical Chemistry and Electrochemistry, RAS.

Atomic coordinates have been deposited in the Cambridge Crystallographic Data Centre [CCDC deposition codes are 1904438 for PdDTolPP, 1904436 for PdD(CMP)PP, 1904437 for PtD(CMP)PP] and can be obtained on request at www.ccdc.cam.ac.uk/data_request/cif.

\section{Synthesis}

Dipyrromethane was prepared by the published procedure. ${ }^{77,78}$ Non-phosphorylated free-base $\mathrm{A}_{2}$-type porphyrins, namely 5,15-bis( $p$-tolyl)porphyrin ( $\left.\mathbf{H}_{2} \mathbf{D T o l P}\right),{ }^{79,80} 5,15$ $\operatorname{bis}\left[p\right.$-(methoxycarbonyl)phenyl]porphyrin $\left[\mathbf{H}_{2} \mathbf{D}(\mathbf{C M P}) \mathbf{P}\right],{ }^{81}$ 5,15-dimesitylporphyrin $\left(\mathbf{H}_{2}\right.$ DMesP) ${ }^{82,83}$ and $5,10,15$-trimesitylporphyrin $\left(\mathbf{H}_{2}\right.$ TMesP) ${ }^{84}$ were obtained by literature methods.

The starting free-base phosphorylated porphyrins 10-(diethoxyphosphoryl)-5,15$\operatorname{bis}\left(p\right.$-tolyl)porphyrin $\quad\left(\mathbf{H}_{2}\right.$ DTolPP $) \quad$ and $\quad$ 10-diethoxyphosphoryl-5,15-bis $[p$ (methoxycarbonyl)phenyl]porphyrin $\left[\mathbf{H}_{2} \mathbf{D}(\mathbf{C M P}) \mathbf{P P}\right]$, 10-(diethoxyphosphoryl)-5,15dimesitylporphyrin (H2DMesPP), and 5-(diethoxyphosphoryl)-10,15,20trimesitylporphyrin (H2TMesPP) were prepared according to the published procedures. $^{29}$ 
General procedure for preparation of Pd(II) complexes. A solution of the freebase porphyrin $\mathbf{H}_{2} \mathbf{R}^{1} \mathbf{P}-\mathbf{H}_{2} \mathbf{R}^{4} \mathbf{P}$ or $\mathbf{H}_{2} \mathbf{R}^{1} \mathbf{P P}-\mathbf{H}_{2} \mathbf{R}^{4} \mathbf{P P}$ in a $\mathrm{CHCl}_{3} / \mathrm{CH}_{3} \mathrm{CN}$ mixture was stirred and heated. During refluxing, $\mathrm{Pd}(\mathrm{OAc})_{2}$ (4-16 equiv.) was added into the flask. The reaction mixture was further stirred until complete conversion of starting porphyrin. The degree of consumption of the porphyrin was monitored by MALDI-TOF massspectrometry and UV-vis spectroscopy. After cooling to room temperature, the solvent was removed under reduced pressure. The residue was purified by column chromatography on silica gel and gel permeation chromatography to afford $\mathbf{P d R} \mathbf{R}^{\mathbf{1}} \mathbf{P}-$ $\mathbf{P d R}^{4} \mathbf{P}$ or $\mathbf{P d R}{ }^{1} \mathbf{P P}-\mathbf{P d R}^{4} \mathbf{P P}$.

[5,15-Bis(p-tolyl)porphyrinato]palladium(II) (PdDTolP) was prepared from 20 $\mathrm{mg}(0.041 \mathrm{mmol})$ of $\mathbf{H}_{2} \mathbf{D T o l P}$ and $37 \mathrm{mg}(0.163 \mathrm{mmol})$ of $\mathrm{Pd}(\mathrm{OAc})_{2}$ dissolved in 11 $\mathrm{mL}$ of a $\mathrm{CHCl}_{3} / \mathrm{CH}_{3} \mathrm{CN}(80: 20 \mathrm{v} / \mathrm{v})$ mixture that was refluxed for $15 \mathrm{~min}$. The resulting solid was purified by column chromatography on silica gel using $\mathrm{CH}_{2} \mathrm{Cl}_{2}$ as eluent to give PdDTolP as a pink purple crystalline powder $(25.4 \mathrm{mg}, 100 \%) .{ }^{1} \mathrm{H}$ NMR (600 $\left.\mathrm{MHz}, \mathrm{CDCl}_{3}, 25^{\circ} \mathrm{C}\right): \delta_{\mathrm{H}} 2.73\left(\mathrm{~s}, 6 \mathrm{H}, \mathrm{Ph}-\underline{\mathrm{CH}}_{3}\right), 7.59\left(\mathrm{~d},{ }^{3} J_{\mathrm{H}, \mathrm{H}}=7.6 \mathrm{~Hz}, 4 \mathrm{H}, m-\mathrm{Ph}\right), 8.10$ $\left(\mathrm{d},{ }^{3} J_{\mathrm{H}, \mathrm{H}}=7.8 \mathrm{~Hz}, 4 \mathrm{H}, o-\mathrm{Ph}\right), 9.04\left(\mathrm{~d},{ }^{3} J_{\mathrm{H}, \mathrm{H}}=4.7 \mathrm{~Hz}, 4 \mathrm{H}, \mathrm{H} \beta\right), 9.28\left(\mathrm{~d},{ }^{3} J_{\mathrm{H}, \mathrm{H}}=4.7 \mathrm{~Hz}\right.$, $4 \mathrm{H}, \mathrm{H} \beta$ ), 10.26 (s, 2H, $\mathrm{H}_{\text {meso }}$ ). MS (MALDI-TOF): $m / z=594.08$ ([M] $]^{+}$, calcd. for $\left.\mathrm{C}_{34} \mathrm{H}_{24} \mathrm{~N}_{4} \mathrm{Pd} m / z=594.10\right)$. HRMS (ESI): $m / z=594.10468\left([\mathrm{M}]^{+}\right.$, calcd. for $\mathrm{C}_{34} \mathrm{H}_{24} \mathrm{~N}_{4} \mathrm{Pd}$ $m / z$ 594.10303). UV-vis [toluene; $\left.\lambda_{\max }, \mathrm{nm}(\log \varepsilon)\right]: 406$ (5.50), 514 (4.23), 544 (3.96). IR (neat, $\mathrm{cm}^{-1}$ ): $v_{\max } 2952(\mathrm{w}), 2914(\mathrm{~m}), 2849(\mathrm{~m}), 1729(\mathrm{~m}), 1537(\mathrm{w}), 1509(\mathrm{w}), 1457$ (w), $1418(\mathrm{w}), 1391(\mathrm{w}), 1376(\mathrm{w}), 1335(\mathrm{w}), 1302(\mathrm{w}), 1234(\mathrm{w}), 1216(\mathrm{w}), 1194(\mathrm{w})$, 1179 (m), 1102 (w), 1068 (m), 1046 (m), 1006 (s), 944 (w), 901 (w), 853 (s), 797 (m), 779 (s), $721(\mathrm{~s}), 693(\mathrm{~s}), 586(\mathrm{w}), 554(\mathrm{w})$.

\section{$\{5,15-B i s[p-(m e t h o x y c a r b o n y l) p h e n y l]$ porphyrinato $\}$ palladium(II)}

[PdD(CMP)P] was prepared from $20 \mathrm{mg}(0.035 \mathrm{mmol})$ of $\mathbf{H}_{2} \mathbf{D}(\mathbf{C M P}) \mathbf{P}$ and $31 \mathrm{mg}$ $(0.138 \mathrm{mmol})$ of $\mathrm{Pd}(\mathrm{OAc})_{2}$ dissolved in $9 \mathrm{~mL}$ of a $\mathrm{CHCl}_{3} / \mathrm{CH}_{3} \mathrm{CN}(80: 20 \mathrm{v} / \mathrm{v})$ mixture. The reaction mixture was refluxed for $15 \mathrm{~min}$. The resulting solid was purified by column chromatography on silica gel using $\mathrm{CH}_{2} \mathrm{Cl}_{2}$ as eluent to give $\mathbf{P d D}(\mathbf{C M P}) \mathbf{P}$ as a pink purple crystalline powder $(19.2 \mathrm{mg}, 83 \%) .{ }^{1} \mathrm{H} \mathrm{NMR}\left(600 \mathrm{MHz}, \mathrm{CDCl}_{3}, 25{ }^{\circ} \mathrm{C}\right): \delta_{\mathrm{H}}$ $4.14\left(\mathrm{~s}, 6 \mathrm{H}, \mathrm{Ph}-\mathrm{COOC}_{3}{ }_{3}\right), 8.31\left(\mathrm{~d},{ }^{3} J_{\mathrm{H}, \mathrm{H}}=8.3 \mathrm{~Hz}, 4 \mathrm{H}, o-\mathrm{Ph}\right), 8.48\left(\mathrm{~d},{ }^{3} J_{\mathrm{H}, \mathrm{H}}=8.3 \mathrm{~Hz}\right.$, $4 \mathrm{H}, m-\mathrm{Ph}), 8.96\left(\mathrm{~d},{ }^{3} J_{\mathrm{H}, \mathrm{H}}=4.7 \mathrm{~Hz}, 4 \mathrm{H}, \mathrm{H} \beta\right), 9.32\left(\mathrm{~d},{ }^{3} J_{\mathrm{H}, \mathrm{H}}=4.8 \mathrm{~Hz}, 4 \mathrm{H}, \mathrm{H} \beta\right), 10.32(\mathrm{~s}$, $2 \mathrm{H}, \mathrm{H}_{\text {meso }}$ ). MS (MALDI-TOF): $m / z=682.11\left([\mathrm{M}]^{+}\right.$, calcd. for $\mathrm{C}_{36} \mathrm{H}_{24} \mathrm{~N}_{4} \mathrm{O}_{4} \mathrm{Pd} m / z=$ 682.08). HRMS (ESI): $m / z=682.08240\left([\mathrm{M}]^{+}\right.$, calcd. for $\mathrm{C}_{36} \mathrm{H}_{24} \mathrm{~N}_{4} \mathrm{O}_{4} \mathrm{Pd} \mathrm{m} / z=$ 682.08269). UV-vis [toluene; $\lambda_{\max }, \mathrm{nm}(\log \varepsilon)$ ]: 406 (4.97), 514 (3.94), 544 (3.54). IR 
(neat, $\left.\mathrm{cm}^{-1}\right): v_{\max } 2917(\mathrm{w}), 2849(\mathrm{w}), 1715(\mathrm{~s}, \mathrm{C}=\mathrm{O}), 1603(\mathrm{w}), 1540(\mathrm{w}), 1507(\mathrm{w})$, 1457 (w), 1427 (w), 1397 (w), 1337 (w), 1305 (w), 1270 (br, m), 1194 (w), 1176 (w), 1152 (w), 1107 (m), 1095 (m), 1071 (m), 1009 (s), 969 (w), 919 (w), 874 (w), 847 (s), $821(\mathrm{~m}), 780(\mathrm{~s}), 754(\mathrm{~s}), 723(\mathrm{~s}), 693$ (s), $638(\mathrm{w}), 592(\mathrm{w}), 569(\mathrm{w}), 554(\mathrm{~m})$.

[10-(Diethoxyphosphoryl)-5,15-bis(p-tolyl)porphyrinato]palladium(II) (PdDTolPP) was prepared from $7 \mathrm{mg}(0.011 \mathrm{mmol})$ of $\mathbf{H}_{2}$ DTolPP and $10 \mathrm{mg}(0.045$ mmol) of $\mathrm{Pd}(\mathrm{OAc})_{2}$ dissolved in $3 \mathrm{~mL}$ of a $\mathrm{CHCl}_{3} / \mathrm{CH}_{3} \mathrm{CN}(80: 20 \mathrm{v} / \mathrm{v})$ mixture. The reaction mixture was refluxed for $15 \mathrm{~min}$. The resulting solid was purified by column chromatography on silica gel using a $\mathrm{CHCl}_{3} / n$-hexane $(1: 1 \mathrm{v} / \mathrm{v})$ as eluent to give PdDTolPP as a pink purple crystalline powder $(8.5 \mathrm{mg}, 100 \%) .{ }^{1} \mathrm{H}$ NMR $(600 \mathrm{MHz}$, $\left.\mathrm{CDCl}_{3} / \mathrm{CD}_{3} \mathrm{OD} 2: 1 \mathrm{v} / \mathrm{v}, 25{ }^{\circ} \mathrm{C}\right): \delta_{\mathrm{H}} 1.16\left(\mathrm{t},{ }^{3} J_{\mathrm{H}, \mathrm{H}}=7.0 \mathrm{~Hz}, 6 \mathrm{H}, \mathrm{OCH}_{2} \mathrm{CH}_{3}\right), 2.53(\mathrm{~s}, 6 \mathrm{H}$, $\left.\mathrm{Ph}-\underline{\mathrm{CH}}_{3}\right), 3.98-4.05\left(\mathrm{~m}, 2 \mathrm{H}, \mathrm{OC}_{2} \underline{C H}_{3}\right), 4.24-4.31\left(\mathrm{~m}, 2 \mathrm{H}, \mathrm{OC}_{2}{ }_{2} \mathrm{CH}_{3}\right), 7.39\left(\mathrm{~d},{ }^{3} J_{\mathrm{H}, \mathrm{H}}=\right.$ $7.6 \mathrm{~Hz}, 4 \mathrm{H}, m-\mathrm{Ph}), 7.83\left(\mathrm{~d},{ }^{3} J_{\mathrm{H}, \mathrm{H}}=7.7 \mathrm{~Hz}, 4 \mathrm{H}, o-\mathrm{Ph}\right), 8.70\left(\mathrm{~d},{ }^{3} J_{\mathrm{H}, \mathrm{H}}=4.7 \mathrm{~Hz}, 2 \mathrm{H}, \mathrm{H} \beta\right)$, $8.78\left(\mathrm{~d},{ }^{3} J_{\mathrm{H}, \mathrm{H}}=5.1 \mathrm{~Hz}, 2 \mathrm{H}, \mathrm{H} \beta\right), 9.02\left(\mathrm{~d},{ }^{3} J_{\mathrm{H}, \mathrm{H}}=4.6 \mathrm{~Hz}, 2 \mathrm{H}, \mathrm{H} \beta\right), 10.02\left(\mathrm{~s}, 1 \mathrm{H}, \mathrm{H}_{\text {meso }}\right)$, $10.08\left(\mathrm{~d},{ }^{3} J_{\mathrm{H}, \mathrm{H}}=5.1 \mathrm{~Hz}, 2 \mathrm{H}, \mathrm{H} \beta\right) .{ }^{31} \mathrm{P}\left\{{ }^{1} \mathrm{H}\right\} \mathrm{NMR}\left(600 \mathrm{MHz}, \mathrm{CDCl}_{3} / \mathrm{MeOD} 2: 1 \mathrm{v} / \mathrm{v}, 25\right.$ $\left.{ }^{\circ} \mathrm{C}\right): \delta_{\mathrm{P}}$ 23.17. MS (MALDI-TOF): $\mathrm{m} / z=730.17\left([\mathrm{M}]^{+}\right.$, calcd. for $\mathrm{C}_{38} \mathrm{H}_{33} \mathrm{~N}_{4} \mathrm{O}_{3} \mathrm{PPd} \mathrm{m} / z$ $=730.13)$. HRMS (ESI): $m / z=730.13491\left([\mathrm{M}]^{+}\right.$, calcd. for $\mathrm{C}_{38} \mathrm{H}_{33} \mathrm{~N}_{4} \mathrm{O}_{3} \mathrm{PPd} m / z=$ 730.13196). UV-vis [toluene; $\left.\lambda_{\max }, \mathrm{nm}(\log \varepsilon)\right]: 410$ (5.32), 523 (4.28), 557 (4.37). IR (neat, $\mathrm{cm}^{-1}$ ): $v_{\max } 2976(\mathrm{w}), 2918(\mathrm{w}), 1608(\mathrm{w}), 1539(\mathrm{w}), 1468(\mathrm{w}), 1433(\mathrm{w}), 1391$ (w), 1369 (w), 1329 (w), 1295 (w), 1249 (m), 1214 (w), 1179 (w), $1160(\mathrm{w}), 1089(\mathrm{w})$, 1067 (m), 1043 (w), 1010 (s), 969 (s), 959 (s), 889 (m), 873 (m), 849 (m), 790 (s), 756 (m), $734(\mathrm{~m}), 712(\mathrm{~m}), 696(\mathrm{~m}), 593(\mathrm{~s}), 569(\mathrm{~s})$.

\section{\{10-(Diethoxyphosphoryl)-5,15-bis $[(p-$}

\section{(methoxycarbonyl)phenyl]porphyrinato\}palladium(II) [PdD(CMP)PP] was} prepared from $70 \mathrm{mg}(0.098 \mathrm{mmol})$ of $\mathbf{H}_{2} \mathbf{D}(\mathbf{C M P}) \mathbf{P P}$ and $88 \mathrm{mg}(0.392 \mathrm{mmol})$ of $\mathrm{Pd}(\mathrm{OAc})_{2}$ dissolved in $25 \mathrm{~mL}$ of a $\mathrm{CHCl}_{3} / \mathrm{CH}_{3} \mathrm{CN}(80: 20 \mathrm{v} / \mathrm{v})$ mixture. The reaction mixture was refluxed for $15 \mathrm{~min}$. The resulting solid was purified by column chromatography on silica gel using a $\mathrm{CHCl}_{3} / \mathrm{MeOH}(100: 1 \mathrm{v} / \mathrm{v})$ mixture as eluent to give PdD(CMP)PP as a pink purple crystalline powder (70.4 mg, 91\%). ${ }^{1} \mathrm{H}$ NMR $(600 \mathrm{MHz}$, $\left.\mathrm{CDCl}_{3} / \mathrm{CD}_{3} \mathrm{OD} 2: 1 \mathrm{v} / \mathrm{v}, 25{ }^{\circ} \mathrm{C}\right): \delta_{\mathrm{H}} 1.17\left(\mathrm{t},{ }^{3} J_{\mathrm{H}, \mathrm{H}}=7.0 \mathrm{~Hz}, 6 \mathrm{H}, \mathrm{OCH}_{2} \mathrm{CH}_{3}\right), 3.93(\mathrm{t}, 6 \mathrm{H}$, $\left.\mathrm{PhCOOCH}_{3}\right), 4.01-4.05\left(\mathrm{~m}, 2 \mathrm{H}, \mathrm{OC}_{2} \underline{C H}_{3}\right), 4.27-4.31\left(\mathrm{~m}, 2 \mathrm{H}, \mathrm{OC}_{2} \mathrm{CH}_{3}\right), 8.03$ (d, $\left.{ }^{3} J_{\mathrm{H}, \mathrm{H}}=8.0 \mathrm{~Hz}, 4 \mathrm{H}, o-\mathrm{Ph}\right), 8.25\left(\mathrm{~d},{ }^{3} J_{\mathrm{H}, \mathrm{H}}=8.0 \mathrm{~Hz}, 4 \mathrm{H}, m-\mathrm{Ph}\right), 8.58\left(\mathrm{~d},{ }^{3} J_{\mathrm{H}, \mathrm{H}}=4.7 \mathrm{~Hz}\right.$, $2 \mathrm{H}, \mathrm{H} \beta), 8.68\left(\mathrm{~d},{ }^{3} J_{\mathrm{H}, \mathrm{H}}=5.2 \mathrm{~Hz}, 2 \mathrm{H}, \mathrm{H} \beta\right), 9.01\left(\mathrm{~d},{ }^{3} J_{\mathrm{H}, \mathrm{H}}=4.7 \mathrm{~Hz}, 2 \mathrm{H}, \mathrm{H} \beta\right), 10.01(\mathrm{~s}, 1 \mathrm{H}$, $\left.\mathrm{H}_{\text {meso }}\right), 10.12\left(\mathrm{~d},{ }^{3} J_{\mathrm{H}, \mathrm{H}}=5.2 \mathrm{~Hz}, 2 \mathrm{H}, \mathrm{H} \beta\right) .{ }^{31} \mathrm{P}\left\{{ }^{1} \mathrm{H}\right\} \mathrm{NMR}\left(600 \mathrm{MHz}, \mathrm{CDCl}_{3} / \mathrm{CD}_{3} \mathrm{OD} 2: 1\right.$ 
$\left.\mathrm{v} / \mathrm{v}, 25{ }^{\circ} \mathrm{C}\right): \quad \delta \mathrm{P}$ 22.55. MS (MALDI-TOF): $m / z=818.28\left([\mathrm{M}]^{+}\right.$, calcd. for $\mathrm{C}_{40} \mathrm{H}_{33} \mathrm{~N}_{4} \mathrm{O}_{7} \mathrm{PPd} m / z=818.11$ ). HRMS (ESI): $m / z=818.11239$ ([M] $]^{+}$, calcd. for $\left.\mathrm{C}_{40} \mathrm{H}_{33} \mathrm{~N}_{4} \mathrm{O}_{7} \mathrm{PPd} m / z=818.11162\right), 841.09803\left([\mathrm{M}+\mathrm{Na}]^{+}\right.$, calcd. for $\mathrm{C}_{40} \mathrm{H}_{33} \mathrm{~N}_{4} \mathrm{O}_{7} \mathrm{PPdNa}$ $m / z$ 841.10139). UV-vis [toluene; $\left.\lambda_{\max }, \mathrm{nm}(\log \varepsilon)\right]: 410$ (5.31), 523 (4.25), 557 (4.31). IR (neat, $\mathrm{cm}^{-1}$ ): $v_{\max } 2984$ (w), 2917 (w), 2850 (w), 1719 (s, C=O), 1607 (m), 1541 (w), 1433 (m), 1401 (w), 1391 (w), 1308 (w), 1274 (s), 1253 (s), 1217 (w), 1179 (w), 1162 (w), 1109 (m), 1097 (m), 1072 (w), 1044 (w), 1011 (s), 965 (s), 893 (m), 864 (m), 822 (w), 785 (m), 761 (s), 729 (s), 710 (s), 694 (m), 585 (m), 565 (m), 551 (m).

(5,15-Dimesitylporphyrinato)palladium(II) (PdDMesP) was prepared from $15 \mathrm{mg}$ $(0.027 \mathrm{mmol})$ of $\mathbf{H}_{2} \mathbf{D M e s} \mathbf{P}$ and $98 \mathrm{mg}(0.437 \mathrm{mmol})$ of $\mathrm{Pd}(\mathrm{OAc})_{2}$ in $8 \mathrm{~mL}$ of a $\mathrm{CHCl}_{3} / \mathrm{CH}_{3} \mathrm{CN}(50: 50 \mathrm{v} / \mathrm{v})$ mixture. The reaction mixture was refluxed for $96 \mathrm{~h}$. The resulting solid was purified by silica gel column chromatography and gel permeation chromatography using $\mathrm{CH}_{2} \mathrm{Cl}_{2}$ and $\mathrm{CHCl}_{3}$ as eluents, respectively, to give PdDMesP as an orange crystalline powder $(6 \mathrm{mg}, 34 \%) .{ }^{1} \mathrm{H} \mathrm{NMR}\left(600 \mathrm{MHz}, \mathrm{CDCl}_{3}, 25^{\circ} \mathrm{C}\right): \delta_{\mathrm{H}} 1.81$ (s, 12H,o- $\left.\mathrm{CH}_{3}\right), 2.65\left(\mathrm{~s}, 6 \mathrm{H}, p-\mathrm{CH}_{3}\right), 7.31$ (br s, $\left.4 \mathrm{H}, m-\mathrm{Ph}\right), 8.84\left(\mathrm{~d},{ }^{3} J_{\mathrm{H}, \mathrm{H}}=4.6 \mathrm{~Hz}, 4 \mathrm{H}\right.$, $\mathrm{H} \beta), 9.24\left(\mathrm{~d},{ }^{3} J_{\mathrm{H}, \mathrm{H}}=4.6 \mathrm{~Hz}, 4 \mathrm{H}, \mathrm{H} \beta\right), 10.20\left(\mathrm{~s}, 2 \mathrm{H}, \mathrm{H}_{\text {meso }}\right) .{ }^{13} \mathrm{C}\left\{{ }^{1} \mathrm{H}\right\} \mathrm{NMR}(150 \mathrm{MHz}$, $\left.\mathrm{CDCl}_{3}, 25^{\circ} \mathrm{C}\right): \delta_{\mathrm{c}} 21.50\left(2 \mathrm{C}, p-\mathrm{CH}_{3}\right), 21.55\left(4 \mathrm{C}, o-\mathrm{CH}_{3}\right), 106.49$ (2C, meso-C), 118.91 (2C, meso-C), 127.84 (4C, m-C $\left.\mathrm{C}_{\mathrm{Mes}}\right), 130.27$ (4C, $\beta$-C), 131.42 (4C, $\beta$-C), 137.78 (2C,

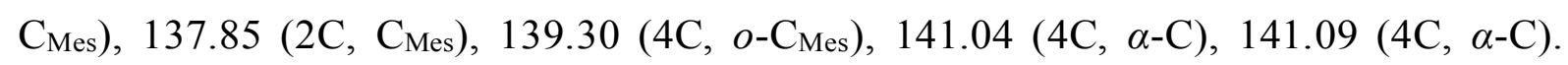
HRMS (ESI): $m / z=650.16779\left([\mathrm{M}]^{+}\right.$, calcd. for $\left.\mathrm{C}_{38} \mathrm{H}_{32} \mathrm{~N}_{4} \mathrm{Pd} m / z=650.16563\right)$. UV-vis [toluene; $\lambda_{\max }, \mathrm{nm}(\log \varepsilon)$ ]: 405 (5.33), 514 (4.31), 546 (3.95). IR (neat, $\mathrm{cm}^{-1}$ ): $v_{\max } 2953$ (m), 2920 (s), 2852 (m), 1717 (br, w), 1609 (w), 1571 (w), 1536 (w), 1456 (br, m), 1396 (w), $1375(\mathrm{~m}), 1338(\mathrm{w}), 1320(\mathrm{w}), 1301(\mathrm{w}), 1260(\mathrm{w}), 1242(\mathrm{w}), 1183(\mathrm{w}), 1165(\mathrm{w})$, $1144(\mathrm{w}), 1060$ (m), $1036(\mathrm{w}), 1011(\mathrm{~s}), 970(\mathrm{w}), 912$ (w), 853 (m), 835 (m), 787 (m), $729(\mathrm{~m}), 721(\mathrm{~m}), 698(\mathrm{~m}), 568(\mathrm{w})$.

(5,15,20-Trimesitylporphyrinato)palladium(II) (PdTMesP) was prepared from 19 $\mathrm{mg}(0.029 \mathrm{mmol})$ of $\mathbf{H}_{\mathbf{2}} \mathbf{T M e s} \mathbf{P}$ and $104 \mathrm{mg}(0.463 \mathrm{mmol})$ of $\mathrm{Pd}(\mathrm{OAc})_{2}$ in $8 \mathrm{~mL}$ of a $\mathrm{CHCl}_{3} / \mathrm{CH}_{3} \mathrm{CN}(50: 50 \mathrm{v} / \mathrm{v})$ mixture. The reaction mixture was refluxed for $96 \mathrm{~h}$. The resulting solid was purified by silica gel column chromatography and gel permeation chromatography using $\mathrm{CH}_{2} \mathrm{Cl}_{2}$ and $\mathrm{CHCl}_{3}$ as eluent, respectively, to give PdTMesP as an orange crystalline powder $(7 \mathrm{mg}, 32 \%) .{ }^{1} \mathrm{H} \mathrm{NMR}\left(600 \mathrm{MHz}, \mathrm{CDCl}_{3}, 2{ }^{\circ} \mathrm{C}\right): \delta_{\mathrm{H}} 1.84$ $\left(\mathrm{s}, 12 \mathrm{H}, o-\mathrm{CH}_{3}\right), 1.85\left(\mathrm{~s}, 6 \mathrm{H}, o-\mathrm{CH}_{3}\right), 2.63\left(\mathrm{~s}, 3 \mathrm{H}, p-\mathrm{CH}_{3}\right), 2.65\left(\mathrm{~s}, 6 \mathrm{H}, p-\mathrm{CH}_{3}\right), 7.27$ (br $\mathrm{s}, 2 \mathrm{H}, m-\mathrm{Ph}), 7.30(\mathrm{br} \mathrm{s}, 4 \mathrm{H}, m-\mathrm{Ph}), 8.66\left(\mathrm{~d},{ }^{3} J_{\mathrm{H}, \mathrm{H}}=4.8 \mathrm{~Hz} 2 \mathrm{H}, \mathrm{H} \beta\right), 8.67\left(\mathrm{~d},{ }^{3} J_{\mathrm{H}, \mathrm{H}}=4.8\right.$ $\mathrm{Hz}, 2 \mathrm{H}, \mathrm{H} \beta), 8.79\left(\mathrm{~d},{ }^{3} J_{\mathrm{H}, \mathrm{H}}=4.6 \mathrm{~Hz}, 2 \mathrm{H}, \mathrm{H} \beta\right), 9.22\left(\mathrm{~d},{ }^{3} J_{\mathrm{H}, \mathrm{H}}=4.6 \mathrm{~Hz}, 2 \mathrm{H}, \mathrm{H} \beta\right), 10.12(\mathrm{~s}$, 
$\left.1 \mathrm{H}, \mathrm{H}_{\text {meso }}\right) .{ }^{13} \mathrm{C}\left\{{ }^{1} \mathrm{H}\right\}$ NMR $\left(150 \mathrm{MHz}, \mathrm{CDCl}_{3}, 25{ }^{\circ} \mathrm{C}\right): \delta_{\mathrm{c}} 21.49\left(1 \mathrm{C}, p-\mathrm{CH}_{3}\right), 21.50(2 \mathrm{C}$, $\left.o-\mathrm{CH}_{3}\right), 21.61$ (4C, o- $\left.\mathrm{CH}_{3}\right), 21.72\left(2 \mathrm{C}, p-\mathrm{CH}_{3}\right), 106.04$ (1C, meso-C), 119.06 (2C, mesoC), 119.71 (1C, meso-C), 127.75 (2C, $m$ - $\left.\mathrm{C}_{\mathrm{Mes}}\right), 127.80$ (4C, $m$ - $\mathrm{C}_{\mathrm{Mes}}$ ), 130.06 (2C, $\beta$-C), 130.22 (4C, $\beta$-C), 131.25 (2C, $\beta$-C), 137,70 (1C, $\mathrm{C}_{\text {Mes }}$ ), 137.75 (2C, $\mathrm{C}_{\text {Mes }}$ ), 137.93 (2C, $\left.\mathrm{C}_{\mathrm{Mes}}\right), 138.06$ (1C, $\left.\mathrm{C}_{\mathrm{Mes}}\right), 139.32$ (6C, o-C $\left.\mathrm{C}_{\mathrm{Mes}}\right), 140.87$ (2C, $\left.\alpha-\mathrm{C}\right), 141.00(2 \mathrm{C}, \alpha-\mathrm{C})$, $141.14(2 \mathrm{C}, \alpha-\mathrm{C}), 141.29(2 \mathrm{C}, \alpha-\mathrm{C}) . \mathrm{HRMS}(\mathrm{ESI}): m / z=768.24534\left([\mathrm{M}]^{+}\right.$, calcd. for $\left.\mathrm{C}_{47} \mathrm{H}_{42} \mathrm{~N}_{4} \mathrm{Pd} m / z=768.24388\right)$. UV-vis [toluene; $\lambda_{\max }, \mathrm{nm}(\log \varepsilon)$ ]: 412 (5.40), 519 (4.37), 550 (3.68). IR (neat, $\mathrm{cm}^{-1}$ ): $v_{\max } 2914$ (w), 2851 (w), $1726(\mathrm{w}), 1609(\mathrm{w}), 1570(\mathrm{w}), 1538$ (w), 1447 (br, m), 1388 (w), 1373 (w), 1341 (w), 1332 (w), 1305 (w), 1242 (w), 1214 (w), $1184(\mathrm{w}), 1166(\mathrm{w}), 1152(\mathrm{w}), 1065(\mathrm{~m}), 1034(\mathrm{w}), 1010(\mathrm{~s}), 952(\mathrm{w}), 902(\mathrm{w}), 864$ (w), 843 (m), 834 (m), 796 (m), 776 (m), 755 (m), 718 (m), 692 (m), 557 (w).

\section{[10-(diethoxyphosphoryl)-5,15-dimesitylporphyrinato]palladium(II)}

(PdDMesPP) was prepared from $25 \mathrm{mg}(0.037 \mathrm{mmol})$ of $\mathbf{H}_{2}$ DMesPP and $66 \mathrm{mg}(0.295$ mmol) of $\mathrm{Pd}(\mathrm{OAc})_{2}$ in $9 \mathrm{~mL}$ of a $\mathrm{CHCl}_{3} / \mathrm{CH}_{3} \mathrm{CN}(50: 50 \mathrm{v} / \mathrm{v})$ mixture. The reaction mixture was refluxed for $2 \mathrm{~h}$. The resulting solid was purified by silica gel column chromatography using a $\mathrm{CH}_{2} \mathrm{Cl}_{2} / \mathrm{MeOH}(95: 5 \mathrm{v} / \mathrm{v})$ mixture as eluent to give PdDMesPP as a pink crystalline powder $(27 \mathrm{mg}, 97 \%) .{ }^{1} \mathrm{H} \mathrm{NMR}\left(600 \mathrm{MHz}, \mathrm{CDCl}_{3}, 25^{\circ} \mathrm{C}\right): \delta_{\mathrm{H}} 1.38$ $\left(\mathrm{t},{ }^{3} J_{\mathrm{H}, \mathrm{H}}=7.0 \mathrm{~Hz}, 6 \mathrm{H}, \mathrm{OCH}_{2} \underline{\mathrm{C}}_{3}\right), 1.83\left(\mathrm{~s}, 12 \mathrm{H}, o-\mathrm{CH}_{3}\right), 2.66\left(\mathrm{~s}, 6 \mathrm{H}, p-\mathrm{CH}_{3}\right), 4.21-4.29$ $\left(\mathrm{m}, 2 \mathrm{H}, \mathrm{OCH}_{2} \mathrm{CH}_{3}\right), 4.51-4.59\left(\mathrm{~m}, 2 \mathrm{H}, \mathrm{OCH}_{2} \mathrm{CH}_{3}\right), 7.32$ (br s, $\left.4 \mathrm{H}, m-\mathrm{Ph}\right), 8.75$ (d, ${ }^{3} J_{\mathrm{H}, \mathrm{H}}$ $=4.6 \mathrm{~Hz}, 2 \mathrm{H}, \mathrm{H} \beta), 8.83\left(\mathrm{~d},{ }^{3} J_{\mathrm{H}, \mathrm{H}}=5.1 \mathrm{~Hz}, 2 \mathrm{H}, \mathrm{H} \beta\right), 9.18\left(\mathrm{~d},{ }^{3} J_{\mathrm{H}, \mathrm{H}}=4.6 \mathrm{~Hz}, 2 \mathrm{H}, \mathrm{H} \beta\right)$, $10.16\left(\mathrm{~s}, 1 \mathrm{H}, \mathrm{H}_{\text {meso }}\right), 10.38\left(\mathrm{~d},{ }^{3} J_{\mathrm{H}, \mathrm{H}}=5.1 \mathrm{~Hz}, 2 \mathrm{H}, \mathrm{H} \beta\right) .{ }^{31} \mathrm{P}\left\{{ }^{1} \mathrm{H}\right\} \mathrm{NMR}\left(600 \mathrm{MHz}, \mathrm{CDCl}_{3}\right.$, $\left.25{ }^{\circ} \mathrm{C}\right): \delta_{\mathrm{P}} 22.59 .{ }^{13} \mathrm{C}\left\{{ }^{1} \mathrm{H}\right\} \operatorname{NMR}\left(150 \mathrm{MHz}, \mathrm{CDCl}_{3}, 25{ }^{\circ} \mathrm{C}\right): \delta_{\mathrm{c}} 16.48\left(\mathrm{~d},{ }^{2} J_{\mathrm{C}, \mathrm{P}}=7.2 \mathrm{~Hz}\right.$, $\left.2 \mathrm{C}, \mathrm{OCH}_{2} \underline{\mathrm{CH}}_{3}\right), 21.49\left(2 \mathrm{C}, p-\mathrm{CH}_{3}\right), 21.55\left(4 \mathrm{C}, o-\mathrm{CH}_{3}\right), 62.77\left(\mathrm{~d},{ }^{2} J_{\mathrm{C}, \mathrm{P}}=4.4 \mathrm{~Hz}, 2 \mathrm{C}\right.$, $\left.\mathrm{OCH}_{2} \mathrm{CH}_{3}\right), 102.03\left(\mathrm{~d},{ }^{2} J_{\mathrm{C}, \mathrm{P}}=185.6 \mathrm{~Hz}, 1 \mathrm{C}\right.$, meso-C), 109.34 (1C, meso-C), 120.27 (2C, meso-C), 127.90 (4C, m-C $\mathrm{C}_{\mathrm{Mes}}$ ), 129.99 (2C, $\beta$-C), 131.48 (2C, $\beta$-C), 132.21 (2C, $\beta$-C), $133.11(2 \mathrm{C}, \beta-\mathrm{C}), 137.61$ (2C, $\left.\mathrm{C}_{\mathrm{Mes}}\right), 138.01$ (2C, $\left.\mathrm{C}_{\mathrm{Mes}}\right), 139.13$ (4C, o- $\left.\mathrm{C}_{\mathrm{Mes}}\right), 140.49$ (2C, $\alpha-\mathrm{C}), 140.74(2 \mathrm{C}, \alpha-\mathrm{C}), 142.18(2 \mathrm{C}, \alpha-\mathrm{C}), 144.21\left(\mathrm{~d},{ }^{2} J_{\mathrm{C}, \mathrm{P}}=18.3 \mathrm{~Hz}, 2 \mathrm{C}, \alpha-\mathrm{CP}\right)$. HRMS (ESI): $m / z=787.19982\left([\mathrm{M}+\mathrm{H}]^{+}\right.$, calcd. for $\left.\mathrm{C}_{42} \mathrm{H}_{42} \mathrm{~N}_{4} \mathrm{O}_{3} \mathrm{PPd} m / z=787.20239\right)$, $809.18205\left([\mathrm{M}+\mathrm{Na}]^{+}\right.$, calcd. for $\left.\mathrm{C}_{42} \mathrm{H}_{41} \mathrm{~N}_{4} \mathrm{O}_{3} \mathrm{PPdNa} m / z=809.18433\right)$. UV-vis [toluene; $\left.\lambda_{\max }, \mathrm{nm}(\log \varepsilon)\right]: 408$ (5.34), 522 (4.23), 555 (4.33). IR (neat, $\mathrm{cm}^{-1}$ ): $v_{\max } 2919$ (w), 2851 (w), $1730(\mathrm{w}), 1608(\mathrm{w}), 1561(\mathrm{w}), 1539(\mathrm{w}), 1476$ (w), 1436 (br, m), 1388 (w), 1374 (w), $1327(\mathrm{w}), 1295$ (w), 1250 (m), $1217(\mathrm{w}), 1165$ (w), $1086(\mathrm{w}), 1063(\mathrm{~m}), 1043$ (m), 1011 (s), 954 (br, m), 883 (m), 853 (m), 834 (w), 800 (m), 782 (m), 736 (m), 725 (m), $713(\mathrm{~m}), 695(\mathrm{~m}), 600(\mathrm{~m}), 578(\mathrm{w}), 560(\mathrm{~m}), 538(\mathrm{~m})$. 
[10-(diethoxyphosphoryl)-5,15,20-trimesitylporphyrinato]palladium(II)

(PdTMesPP) was prepared from $24 \mathrm{mg}(0.030 \mathrm{mmol})$ of H2TMesPP and $54 \mathrm{mg}(0.241$ $\mathrm{mmol})$ of $\mathrm{Pd}(\mathrm{OAc})_{2}$ in $8 \mathrm{~mL}$ of a $\mathrm{CHCl}_{3} / \mathrm{CH}_{3} \mathrm{CN}(50: 50 \mathrm{v} / \mathrm{v})$ mixture. The reaction mixture was refluxed for $2 \mathrm{~h}$. The resulting solid was purified by silica gel column chromatography using a $\mathrm{CH}_{2} \mathrm{Cl}_{2} / \mathrm{MeOH}(95: 5 \mathrm{v} / \mathrm{v})$ mixture as eluent to give PdTMesPP as a pink crystalline powder $(26 \mathrm{mg}, 96 \%) .{ }^{1} \mathrm{H} \mathrm{NMR}\left(600 \mathrm{MHz}, \mathrm{CDCl}_{3}, 25^{\circ} \mathrm{C}\right): \delta_{\mathrm{H}} 1.37$ $\left(\mathrm{t},{ }^{3} J_{\mathrm{H}, \mathrm{H}}=7.0 \mathrm{~Hz}, 6 \mathrm{H}, \mathrm{OCH}_{2} \mathrm{C}_{3}\right), 1.85\left(\mathrm{~s}, 12 \mathrm{H}, o-\mathrm{CH}_{3}\right), 1.86\left(\mathrm{~s}, 6 \mathrm{H}, o-\mathrm{CH}_{3}\right), 2.61(\mathrm{~s}$, $\left.3 \mathrm{H}, p-\mathrm{CH}_{3}\right), 2.64\left(\mathrm{~s}, 6 \mathrm{H}, p-\mathrm{CH}_{3}\right), 4.19-4.27\left(\mathrm{~m}, 2 \mathrm{H}, \mathrm{OC}_{2} \mathrm{CH}_{3}\right), 4.48-4.57(\mathrm{~m}, 2 \mathrm{H}$, $\mathrm{OCH}_{2} \mathrm{CH}_{3}$ ), 7.26 (br s, 2H, $\left.m-\mathrm{Ph}\right), 7.29$ (br s, $\left.4 \mathrm{H}, m-\mathrm{Ph}\right), 8.56\left(\mathrm{~d},{ }^{3} J_{\mathrm{H}, \mathrm{H}}=4.8 \mathrm{~Hz}, 2 \mathrm{H}\right.$, $\mathrm{H} \beta), 8.61\left(\mathrm{~d},{ }^{3} J_{\mathrm{H}, \mathrm{H}}=4.8 \mathrm{~Hz}, 2 \mathrm{H}, \mathrm{H} \beta\right), 8.76\left(\mathrm{~d},{ }^{3} J_{\mathrm{H}, \mathrm{H}}=5.2 \mathrm{~Hz}, 2 \mathrm{H}, \mathrm{H} \beta\right), 10.31\left(\mathrm{~d},{ }^{3} J_{\mathrm{H}, \mathrm{H}}=\right.$ $5.2 \mathrm{~Hz}, 2 \mathrm{H}, \mathrm{H} \beta) .{ }^{31} \mathrm{P}\left\{{ }^{1} \mathrm{H}\right\} 144.21 \mathrm{NMR}\left(600 \mathrm{MHz}, \mathrm{CDCl}_{3}, 25{ }^{\circ} \mathrm{C}\right): \delta_{\mathrm{P}} 22.72 .{ }^{13} \mathrm{C}\left\{{ }^{1} \mathrm{H}\right\}$ $\operatorname{NMR}\left(150 \mathrm{MHz}, \mathrm{CDCl}_{3}, 25^{\circ} \mathrm{C}\right): \delta_{\mathrm{c}} 16.46\left(\mathrm{~d},{ }^{2} J_{\mathrm{C}, \mathrm{P}}=6.6 \mathrm{~Hz}, 2 \mathrm{C}, \mathrm{OCH}_{2} \mathrm{CH}_{3}\right), 21.46(1 \mathrm{C}$, $\left.p-\mathrm{CH}_{3}\right), 21.48\left(2 \mathrm{C}, o-\mathrm{CH}_{3}\right), 21.58\left(4 \mathrm{C}, o-\mathrm{CH}_{3}\right), 21.63\left(2 \mathrm{C}, p-\mathrm{CH}_{3}\right), 62.71\left(\mathrm{~d},{ }^{2} J_{\mathrm{C}, \mathrm{P}}=4.4\right.$ $\left.\mathrm{Hz}, 2 \mathrm{C}, \mathrm{OC}_{2} \mathrm{CH}_{3}\right), 101.35\left(\mathrm{~d},{ }^{2} J_{\mathrm{C}, \mathrm{P}}=187.1 \mathrm{~Hz}, 1 \mathrm{C}\right.$, meso-C), 120.50 (2C, meso-C), 122.92 (1C, meso-C), 127.81 (2C, $m$ - $\left.\mathrm{C}_{\mathrm{Mes}}\right), 127.85$ (4C, $\left.m-\mathrm{C}_{\mathrm{Mes}}\right), 129.79$ (2C, $\beta$-C), 131.00 (2C, $\beta$-C), 131.47 (2C, $\beta$-C), 132,88 (2C, $\beta$-C), 137.40 (1C, $\left.\mathrm{C}_{\mathrm{Mes}}\right), 137.72$ (2C,

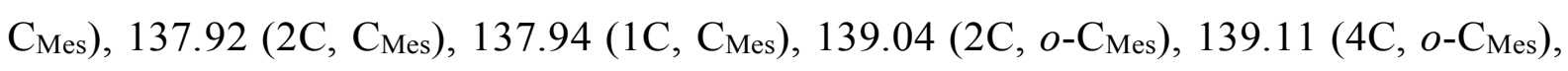
$140.44(2 \mathrm{C}, \alpha-\mathrm{C}), 140.60(2 \mathrm{C}, \alpha-\mathrm{C}), 142.18(2 \mathrm{C}, \alpha-\mathrm{C}), 144.48\left(\mathrm{~d},{ }^{2} J_{\mathrm{C}, \mathrm{P}}=18.2 \mathrm{~Hz}, 2 \mathrm{C}\right.$, $\alpha-\mathrm{CP})$. HRMS (ESI): $m / z=904.27887\left([\mathrm{M}]^{+}\right.$, calcd. for $\mathrm{C}_{51} \mathrm{H}_{51} \mathrm{~N}_{4} \mathrm{O}_{3} \mathrm{PPd} m / z=$ 904.27281), $905.28173\left([\mathrm{M}+\mathrm{H}]^{+}\right.$, calcd. for $\left.\mathrm{C}_{51} \mathrm{H}_{52} \mathrm{~N}_{4} \mathrm{O}_{3} \mathrm{PPd} m / z=905.28064\right)$, $927.26365\left([\mathrm{M}+\mathrm{Na}]^{+}\right.$, calcd. for $\left.\mathrm{C}_{51} \mathrm{H}_{51} \mathrm{~N}_{4} \mathrm{O}_{3} \mathrm{PPdNa} \mathrm{m} / z=927.26258\right)$. UV-vis [toluene; $\left.\lambda_{\max }, \mathrm{nm}(\log \varepsilon)\right]: 415$ (5.38), 527 (4.29), 560 (4.28). IR (neat, $\mathrm{cm}^{-1}$ ): $v_{\max } 2918$ (w), 2852 (w), $1729(\mathrm{w}), 1610(\mathrm{w}), 1561$ (w), $1540(\mathrm{w}), 1435$ (br, m), $1376(\mathrm{w}), 1348(\mathrm{w}), 1333$ (w), 1302 (w), 1252 (m), 1207 (w), 1161 (w), 1088 (w), 1069 (m), 1044 (m), 1011 (s), 953 (br, m), 884 (m), 865 (w), 851 (m), 830 (w), 799 (m), 755 (w), 727 (m), 711 (m), $598(\mathrm{~m}), 575(\mathrm{w}), 561(\mathrm{~m}), 538(\mathrm{~m})$.

General Procedure for Platinum(II) Metalation. A solution of the free-base porphyrin $\mathbf{H}_{2} \mathbf{R}^{1} \mathbf{P}-\mathbf{H}_{2} \mathbf{R}^{4} \mathbf{P}$ or $\mathbf{H}_{2} \mathbf{R}^{1} \mathbf{P P}-\mathbf{H}_{2} \mathbf{R}^{4} \mathbf{P P}$ and $\mathrm{PtCl}_{2}$ (2-10 equiv.) were refluxed in benzonitrile. During the heating, the color of the reaction mixture became brownorange. The degree of conversion was monitored by MALDI-TOF mass-spectrometry and UV-vis spectroscopy. After complete conversion of the starting porphyrin, the reaction mixture was cooled to room temperature and $n$-hexane was added. The resulting precipitate was filtrated, washed two times with $n$-hexane and dissolved in chloroform. 
After evaporation of the solvent, the residue was purified by column chromatography on silica gel to afford $\mathbf{P t R} \mathbf{R}^{1} \mathbf{P}-\mathbf{P t R}^{4} \mathbf{P}$ or $\mathbf{P t R}^{1} \mathbf{P P}-\mathbf{P t R}^{\mathbf{4}} \mathbf{P P}$.

[5,15-Bis(p-tolyl)porphyrinato]platinum(II) (PtDTolP) was prepared from $20 \mathrm{mg}$ $(0.041 \mathrm{mmol})$ of $\mathbf{H}_{2}$ DTolP and $33 \mathrm{mg}(0.123 \mathrm{mmol})$ of $\mathrm{PtCl}_{2}$ dissolved in $7 \mathrm{~mL}$ of benzonitrile. The reaction mixture was stirred under reflux for $4 \mathrm{~h}$. The resulting solid was purified by column chromatography on silica gel using $\mathrm{CH}_{2} \mathrm{Cl}_{2}$ as eluent to give PtDTolP as an orange crystalline powder $(20.6 \mathrm{mg}, 72 \%) .{ }^{1} \mathrm{H} \mathrm{NMR}\left(600 \mathrm{MHz}, \mathrm{CDCl}_{3}\right.$, $\left.25{ }^{\circ} \mathrm{C}\right): \delta_{\mathrm{H}} 2.73\left(\mathrm{~s}, 6 \mathrm{H}, \mathrm{Ph}-\mathrm{CH}_{3}\right), 7.58\left(\mathrm{~d},{ }^{3} J_{\mathrm{H}, \mathrm{H}}=7.6 \mathrm{~Hz}, 4 \mathrm{H}, m-\mathrm{Ph}\right), 8.08\left(\mathrm{~d},{ }^{3} J_{\mathrm{H}, \mathrm{H}}=7.8\right.$ $\mathrm{Hz}, 4 \mathrm{H}, o-\mathrm{Ph}), 8.97\left(\mathrm{~d},{ }^{3} J_{\mathrm{H}, \mathrm{H}}=4.8 \mathrm{~Hz}, 4 \mathrm{H}, \mathrm{H} \beta\right), 9.21\left(\mathrm{~d},{ }^{3} J_{\mathrm{H}, \mathrm{H}}=4.9 \mathrm{~Hz}, 4 \mathrm{H}, \mathrm{H} \beta\right), 10.15$ (s, 2H, $\mathrm{H}_{\text {meso }}$ ). MS (MALDI-TOF): $m / z=684.18\left([\mathrm{M}+\mathrm{H}]^{+}\right.$, calcd. for $\mathrm{C}_{34} \mathrm{H}_{24} \mathrm{~N}_{4} \mathrm{Pt} m / z=$ 684.17). HRMS (ESI): $m / z=683.16445\left([\mathrm{M}]^{+}\right.$, calcd. for $\left.\mathrm{C}_{34} \mathrm{H}_{24} \mathrm{~N}_{4} \mathrm{Pt} m / z=683.16460\right)$. UV-vis [toluene; $\lambda_{\max }, \mathrm{nm}(\log \varepsilon)$ ]: 393 (5.16), 502 (4.38), 531 (4.25). IR (neat, $\mathrm{cm}^{-1}$ ): $v_{\max } 2954(\mathrm{w}), 2916(\mathrm{w}), 2850(\mathrm{w}), 1729(\mathrm{w}), 1541(\mathrm{w}), 1509(\mathrm{w}), 1455(\mathrm{w}), 1395(\mathrm{w})$, 1341 (w), 1326 (w), 1308 (m), 1179 (w), 1103 (w), 1069 (m), 1042 (w), 1012 (s), 943 (w), $897(\mathrm{w}), 854(\mathrm{~s}), 799(\mathrm{~m}), 778(\mathrm{~s}), 721(\mathrm{~s}), 693(\mathrm{~s}), 625(\mathrm{w}), 615(\mathrm{w}), 590(\mathrm{w}), 568$ $(\mathrm{w}), 554(\mathrm{w})$.

\section{[5,15-bis [p-(methoxycarbonyl)phenyl]porphyrinato\}platinum(II) [PtD(CMP)P]} was prepared from $40 \mathrm{mg}(0.07 \mathrm{mmol})$ of $\mathbf{H}_{2} \mathbf{D}(\mathbf{C M P}) \mathbf{P}$ and $56 \mathrm{mg}(0.208 \mathrm{mmol})$ of $\mathrm{PtCl}_{2}$ dissolved in $12 \mathrm{~mL}$ of benzonitrile. The reaction mixture was stirred under reflux for $4 \mathrm{~h}$. The resulting solid was purified by column chromatography on silica gel using $\mathrm{CH}_{2} \mathrm{Cl}_{2}$ as eluent to give $\mathbf{P t D}(\mathbf{C M P}) \mathbf{P}$ as an orange crystalline powder $(25 \mathrm{mg}, 46 \%$ ). ${ }^{1} \mathrm{H}$ NMR $\left(600 \mathrm{MHz}, \mathrm{CDCl}_{3}, 25{ }^{\circ} \mathrm{C}\right): \delta_{\mathrm{H}} 4.14\left(\mathrm{~s}, 6 \mathrm{H}, \mathrm{Ph}-\underline{\mathrm{C}}_{3}\right), 8.30\left(\mathrm{~d},{ }^{3} J_{\mathrm{H}, \mathrm{H}}=7.9 \mathrm{~Hz}\right.$, $4 \mathrm{H}, o-\mathrm{Ph}), 8.47\left(\mathrm{~d},{ }^{3} J_{\mathrm{H}, \mathrm{H}}=8.0 \mathrm{~Hz}, 4 \mathrm{H}, m-\mathrm{Ph}\right), 8.90\left(\mathrm{~d},{ }^{3} J_{\mathrm{H}, \mathrm{H}}=4.8 \mathrm{~Hz}, 4 \mathrm{H}, \mathrm{H} \beta\right), 9.26(\mathrm{~d}$, $\left.{ }^{3} J_{\mathrm{H}, \mathrm{H}}=4.8 \mathrm{~Hz}, 4 \mathrm{H}, \mathrm{H} \beta\right), 10.21\left(\mathrm{~s}, 2 \mathrm{H}, \mathrm{H}_{\text {meso }} \text { ). MS (MALDI-TOF): } m / z=771.15 \text { ([M] }\right]^{+}$, calcd. for $\mathrm{C}_{36} \mathrm{H}_{24} \mathrm{~N}_{4} \mathrm{O}_{4} \mathrm{Pt} m / z=771.14$ ). HRMS (ESI): $m / z=771.14461$ ([M] $]^{+}$, calcd. for $\left.\mathrm{C}_{36} \mathrm{H}_{24} \mathrm{~N}_{4} \mathrm{O}_{4} \mathrm{Pt} m / z=771.14428\right)$. UV-vis $\left[\mathrm{CHCl}_{3} ; \lambda_{\max }, \mathrm{nm}(\log \varepsilon)\right]: 393$ (5.31), 502 (4.25), 531 (4.14). IR (neat, $\mathrm{cm}^{-1}$ ): $v_{\max } 2953$ (m), 2915 (s), 2849 (m), 1716 (s, C=O), 1604 (w), 1541 (w), 1492 (w), 1457 (w), $1428(w), 1398$ (w), $1376(w), 1363(w), 1310$ (w), 1222 (w), 1195 (w), 1179 (m), 1096 (m), 1075 (m), 1047 (w), 1013 (m), 968 (w), $928(\mathrm{w}), 855(\mathrm{w}), 848(\mathrm{w}), 821(\mathrm{w}), 782(\mathrm{~m}), 755(\mathrm{~m}), 723(\mathrm{~s}), 694(\mathrm{~m}), 646(\mathrm{w}), 615$ (w), $594(\mathrm{w}), 569(\mathrm{w}), 554(\mathrm{w})$.

\section{[10-(Diethoxyphosphoryl)-5,15-bis(p-tolyl)porphyrinato]platinum(II)}

(PtDTolPP) was prepared from $7 \mathrm{mg}(0.011 \mathrm{mmol})$ of $\mathbf{H}_{2}$ DTolPP and $7.5 \mathrm{mg}(0.022$ $\mathrm{mmol}$ ) of $\mathrm{PtCl}_{2}$ dissolved in $2 \mathrm{~mL}$ of benzonitrile. The reaction mixture was stirred under 
reflux for $4 \mathrm{~h}$. The resulting solid was purified by column chromatography on silica gel using $\mathrm{CHCl}_{3} / n$-hexane $(1: 1 \mathrm{v} / \mathrm{v})$ as eluent to give PtDTolPP as an orange red crystalline powder (7.8 mg, 85\%). ${ }^{1} \mathrm{H} \mathrm{NMR}\left(600 \mathrm{MHz}, \mathrm{CDCl}_{3} / \mathrm{CD}_{3} \mathrm{OD} 2: 1 \mathrm{v} / \mathrm{v}, 25^{\circ} \mathrm{C}\right): \delta_{\mathrm{H}} 1.16(\mathrm{t}$, $\left.{ }^{3} J_{\mathrm{H}, \mathrm{H}}=7.0 \mathrm{~Hz}, 6 \mathrm{H}, \mathrm{OCH}_{2} \underline{\mathrm{CH}}_{3}\right), 2.53\left(\mathrm{~s}, 6 \mathrm{H}, \mathrm{Ph}-\mathrm{C}_{3}\right), 3.98-4.05\left(\mathrm{~m}, 2 \mathrm{H}, \mathrm{OC}_{\underline{2}} \mathrm{CH}_{3}\right)$, $4.24-4.30\left(\mathrm{~m}, 2 \mathrm{H}, \mathrm{OC}_{2} \mathrm{CH}_{3}\right), 7.39\left(\mathrm{~d},{ }^{3} J_{\mathrm{H}, \mathrm{H}}=7.6 \mathrm{~Hz}, 4 \mathrm{H}, m-\mathrm{Ph}\right), 7.83\left(\mathrm{~d},{ }^{3} J_{\mathrm{H}, \mathrm{H}}=7.7\right.$ $\mathrm{Hz}, 4 \mathrm{H}, o-\mathrm{Ph}), 8.68\left(\mathrm{~d},{ }^{3} J_{\mathrm{H}, \mathrm{H}}=4.8 \mathrm{~Hz}, 2 \mathrm{H}, \mathrm{H} \beta\right), 8.74\left(\mathrm{~d},{ }^{3} J_{\mathrm{H}, \mathrm{H}}=5.2 \mathrm{~Hz}, 2 \mathrm{H}, \mathrm{H} \beta\right), 8.99$ $\left(\mathrm{d},{ }^{3} J_{\mathrm{H}, \mathrm{H}}=4.8 \mathrm{~Hz}, 2 \mathrm{H}, \mathrm{H} \beta\right), 9.96\left(\mathrm{~s}, 1 \mathrm{H}, \mathrm{H}_{\text {meso }}\right), 10.06\left(\mathrm{~d},{ }^{3} J_{\mathrm{H}, \mathrm{H}}=5.3 \mathrm{~Hz}, 2 \mathrm{H}, \mathrm{H} \beta\right) .{ }^{31} \mathrm{P}\left\{{ }^{1} \mathrm{H}\right\}$ NMR (600 MHz, $\left.\mathrm{CDCl}_{3} / \mathrm{CD}_{3} \mathrm{OD} 2: 1 \mathrm{v} / \mathrm{v}, 25^{\circ} \mathrm{C}\right): \delta_{\mathrm{P}} 22.52$. MS (MALDI-TOF): $\mathrm{m} / \mathrm{z}=$ $820.23\left([\mathrm{M}+\mathrm{H}]^{+}\right.$, calcd. for $\left.\mathrm{C}_{38} \mathrm{H}_{34} \mathrm{~N}_{4} \mathrm{O}_{3} \mathrm{PPt} m / z=820.19\right)$. HRMS (ESI): $m / z=$ $819.19732\left([\mathrm{M}]^{+}\right.$, calcd. for $\left.\mathrm{C}_{38} \mathrm{H}_{33} \mathrm{~N}_{4} \mathrm{O}_{3} \mathrm{PPt} m / z=819.19357\right)$. UV-vis [toluene; $\lambda$ max, $\mathrm{nm}(\log \varepsilon)]: 396$ (5.41), 510 (4.23), 546 (4.42). IR (neat, $\left.\mathrm{cm}^{-1}\right): v_{\max } 2952(\mathrm{~m}), 2920(\mathrm{~m})$, 1609 (w), 1541 (w), 1439 (w), 1391 (w), 1375 (w), 1363 (w), 1333 (w), 1311 (w), 1246 (m, P=O), 1216 (w), 1179 (w), 1162 (w), 1088 (w), 1069 (m), 1042 (w), 1015 (s), 966 (s), $963(\mathrm{~m}), 892(\mathrm{~m}), 873$ (m), 850 (w), 800 (s), 792 (m), 781 (m), 710 (m), 694 (m), $664(\mathrm{w}), 640(\mathrm{w}), 603(\mathrm{~s}), 571(\mathrm{~s}), 552(\mathrm{w})$.

\section{\{10-(Diethoxyphosphoryl)-5,15-bis [p-}

(methoxycarbonyl)phenyl]porphyrinato\} platinum(II) [PtD(CMP)PP] was prepared from $15 \mathrm{mg}(0.021 \mathrm{mmol})$ of $\mathbf{H}_{2} \mathbf{D}$ (CMP)PP and $11.2 \mathrm{mg}$ (0.042) of $\mathrm{PtCl}_{2}$ dissolved in $4 \mathrm{~mL}$ of benzonitrile. The reaction mixture was stirred under reflux for $4 \mathrm{~h}$. The resulting solid was purified by column chromatography on silica gel using $\mathrm{CHCl}_{3} / n$-hexane $(1: 1$ v/v) as eluent to give PtD(CMP)PP as an red orange crystalline powder (12.3 $\mathrm{mg}, 70 \%)$. ${ }^{1} \mathrm{H}$ NMR $\left(600 \mathrm{MHz}, \mathrm{CDCl}_{3} / \mathrm{CD}_{3} \mathrm{OD}(2: 1 \mathrm{v} / \mathrm{v}), 25^{\circ} \mathrm{C}\right): \delta_{\mathrm{H}} 1.15\left(\mathrm{t},{ }^{3} J_{\mathrm{H}, \mathrm{H}}=7.0 \mathrm{~Hz}, 6 \mathrm{H}\right.$, $\left.\mathrm{OCH}_{2} \underline{\mathrm{CH}}_{3}\right), 3.92\left(\mathrm{~s}, 6 \mathrm{H}, \mathrm{PhCOOCH}_{3}\right), 3.99-4.06\left(\mathrm{~m}, 2 \mathrm{H}, \underline{\mathrm{OCH}}_{2} \underline{C H}_{3}\right), 4.24-4.30(\mathrm{~m}, 2 \mathrm{H}$, $\left.\mathrm{OCH}_{2} \mathrm{CH}_{3}\right), 8.01\left(\mathrm{~d},{ }^{3} J_{\mathrm{H}, \mathrm{H}}=7.9 \mathrm{~Hz}, 4 \mathrm{H}, o-\mathrm{Ph}\right), 8.23\left(\mathrm{~d},{ }^{3} J_{\mathrm{H}, \mathrm{H}}=7.9 \mathrm{~Hz}, 4 \mathrm{H}, m-\mathrm{Ph}\right), 8.53$ $\left(\mathrm{d},{ }^{3} J_{\mathrm{H}, \mathrm{H}}=4.8 \mathrm{~Hz}, 2 \mathrm{H}, \mathrm{H} \beta\right), 8.62\left(\mathrm{~d},{ }^{3} J_{\mathrm{H}, \mathrm{H}}=5.3 \mathrm{~Hz}, 2 \mathrm{H}, \mathrm{H} \beta\right), 8.95\left(\mathrm{~d},{ }^{3} J_{\mathrm{H}, \mathrm{H}}=4.8 \mathrm{~Hz}, 2 \mathrm{H}\right.$, $\mathrm{H} \beta), 9.91\left(\mathrm{~s}, 1 \mathrm{H}, \mathrm{H}_{\text {meso }}\right), 10.08\left(\mathrm{~d},{ }^{3} J_{\mathrm{H}, \mathrm{H}}=5.3 \mathrm{~Hz}, 2 \mathrm{H}, \mathrm{H} \beta\right) .{ }^{31} \mathrm{P}\left\{{ }^{1} \mathrm{H}\right\} \mathrm{NMR}(600 \mathrm{MHz}$, $\left.\mathrm{CDCl}_{3} / \mathrm{CD}_{3} \mathrm{OD} 2: 1 \mathrm{v} / \mathrm{v}, 25^{\circ} \mathrm{C}\right): \delta_{\mathrm{P}} 21.91$. MS (MALDI-TOF): $m / z=908.04\left([\mathrm{M}+\mathrm{H}]^{+}\right.$, calcd. for $\mathrm{C}_{40} \mathrm{H}_{34} \mathrm{~N}_{4} \mathrm{O}_{7} \mathrm{PPt} m / z=908.17$ ). HRMS (ESI): $m / z=907.17703$ ([M] $]^{+}$, calcd. for $\left.\mathrm{C}_{40} \mathrm{H}_{33} \mathrm{~N}_{4} \mathrm{O}_{7} \mathrm{PPt} m / z=907.17324\right)$. UV-vis [toluene; $\lambda_{\max }, \mathrm{nm}(\log \varepsilon)$ ]: 396 (5.51), 510 (4.44), 546 (4.61). IR (neat, $\mathrm{cm}^{-1}$ ): $v_{\max } 2980$ (w), 2921 (w), 2849 (w), $1717(\mathrm{~s}, \mathrm{C}=\mathrm{O})$, 1607 (m), 1566 (w), 1545 (w), 1433 (m), 1392 (w), 1307 (w), 1274 (s, P=O), 1252 (s, P = O), $1217(\mathrm{w}), 1178(\mathrm{w}), 1162(\mathrm{w}), 1110(\mathrm{~m}), 1089(\mathrm{~m}), 1074(\mathrm{w}), 1043(\mathrm{w}), 1013(\mathrm{~s})$, 960 (s), 893 (m), 865 (m), 822 (w), 786 (m), 761 (s), 728 (s), 709 (s), 694 (m), 586 (s), $561(\mathrm{~s}), 551(\mathrm{~m})$. 
(5,15-Dimesitylporphyrinato)platinum(II) (PtDMesP) was prepared from $21 \mathrm{mg}$ $(0.038 \mathrm{mmol})$ of $\mathbf{H}_{2}$ DMesP and $102 \mathrm{mg}(0.384 \mathrm{mmol})$ of $\mathrm{PtCl}_{2}$ in $6 \mathrm{~mL}$ of benzonitrile. The reaction mixture was stirred under reflux for $18 \mathrm{~h}$. The resulting solid was purified by silica gel column chromatography and gel permeation chromatography using $\mathrm{CHCl}_{3}$ as eluent to give PtDMesP as an orange crystalline powder (22 mg, 78\%). ${ }^{1} \mathrm{H}$ NMR (600 $\left.\mathrm{MHz} \mathrm{CDCl}_{3}, 25^{\circ} \mathrm{C}\right): \delta_{\mathrm{H}} 1.86\left(\mathrm{~s}, 12 \mathrm{H}, o-\mathrm{CH}_{3}\right), 2.66\left(\mathrm{~s}, 6 \mathrm{H}, p-\mathrm{CH}_{3}\right), 7.32(\mathrm{br} \mathrm{s}, 4 \mathrm{H}, m-$ $\mathrm{Ph}), 8.80\left(\mathrm{~d},{ }^{3} J_{\mathrm{H}, \mathrm{H}}=4.8 \mathrm{~Hz}, 4 \mathrm{H}, \mathrm{H} \beta\right), 9.18\left(\mathrm{~d},{ }^{3} J_{\mathrm{H}, \mathrm{H}}=4.8 \mathrm{~Hz}, 4 \mathrm{H}, \mathrm{H} \beta\right), 10.11(\mathrm{~s}, 2 \mathrm{H}$, $\left.\mathrm{H}_{\text {meso }}\right) .{ }^{13} \mathrm{C}\left\{{ }^{1} \mathrm{H}\right\}$ NMR $\left(150 \mathrm{MHz}, \mathrm{CDCl}_{3}, 25^{\circ} \mathrm{C}\right): \delta_{\mathrm{c}} 21.49\left(4 \mathrm{C}, o-\mathrm{CH}_{3}\right), 21.50(2 \mathrm{C}, p-$ $\left.\mathrm{CH}_{3}\right), 107.24$ (2C, meso-C), 119.48 (2C, meso-C), 127.90 (4C, $m$-C $\mathrm{C}_{\mathrm{Mes}}$ ), 129.96 (4C, $\beta$ C), 131.35 (4C, $\beta$-C), 137.37 (2C, $\left.\mathrm{C}_{\mathrm{Mes}}\right), 137.91$ (2C, $\mathrm{C}_{\mathrm{Mes}}$ ), 139.23 (4C, o-C $\left.\mathrm{C}_{\mathrm{Mes}}\right), 140.34$ $(4 \mathrm{C}, \alpha-\mathrm{C}), 140.42(4 \mathrm{C}, \alpha-\mathrm{C}) . \operatorname{HRMS}(\mathrm{ESI}): m / z=739.22774\left([\mathrm{M}]^{+}\right.$, calcd. for $\left.\mathrm{C}_{38} \mathrm{H}_{32} \mathrm{~N}_{4} \mathrm{Pt} m / z=739.22723\right), 762.21649\left([\mathrm{M}+\mathrm{Na}]^{+}\right.$, calcd. for $\mathrm{C}_{38} \mathrm{H}_{32} \mathrm{~N}_{4} \mathrm{PtNa} m / z=$ 762.21669). UV-vis [toluene; $\left.\lambda_{\max }, \mathrm{nm}(\log \varepsilon)\right]: 391$ (5.38), 501 (4.27), 532 (4.19). IR (neat, $\left.\mathrm{cm}^{-1}\right): v_{\max } 2954(\mathrm{~m}), 2921(\mathrm{~m}), 2852(\mathrm{~m}), 1828(\mathrm{w}), 1786(\mathrm{w}), 1736(\mathrm{w}), 1711$ (w), 1606 (w), 1589 (w), 1570 (w), 1521 (m), 1447 (br, m), 1398 (w), 1371 (m), 1341 (w), $1324(\mathrm{w}), 1306(\mathrm{~m}), 1260$ (w), 1242 (w), 1217 (w), $1164(\mathrm{w}), 1144(\mathrm{w}), 1070(\mathrm{~m})$, 1059 (m), 1041 (w), 1013 (s), 915 (w), 853 (s), 836 (m), 789 (m), 778 (s), 758 (m), 720 (s), $698(\mathrm{~s}), 672(\mathrm{w}), 646(\mathrm{w}), 567(\mathrm{w})$.

(5,15,20-Trimesitylporphyrinato)platinum(II) (PtTMesP) was prepared from 10 $\mathrm{mg}(0.015 \mathrm{mmol})$ of $\mathbf{H}_{2}$ TMesP and $40 \mathrm{mg}(0.150 \mathrm{mmol})$ of $\mathrm{PtCl}_{2}$ in $3 \mathrm{~mL}$ of benzonitrile. The reaction mixture was stirred under reflux for $50 \mathrm{~h}$. The resulting solid was purified by silica gel column chromatography and gel permeation chromatography using $\mathrm{CHCl}_{3}$ as eluent to give PtTMesP as an orange-brown crystalline powder $(11 \mathrm{mg}, 85 \%) .{ }^{1} \mathrm{H}$ NMR $\left(600 \mathrm{MHz}, \mathrm{CDCl}_{3}, 25^{\circ} \mathrm{C}\right): \delta_{\mathrm{H}} 1.87\left(\mathrm{~s}, 18 \mathrm{H}, o-\mathrm{CH}_{3}\right), 2.62\left(\mathrm{~s}, 3 \mathrm{H}, p-\mathrm{CH}_{3}\right), 2.64(\mathrm{~s}$, $\left.6 \mathrm{H}, p-\mathrm{CH}_{3}\right), 7.27$ (br s, 2H, $\left.m-\mathrm{Ph}\right), 7.30$ (br s, 4H, $\left.m-\mathrm{Ph}\right), 8.61\left(\mathrm{~d},{ }^{3} J_{\mathrm{H}, \mathrm{H}}=4.8 \mathrm{~Hz}, 2 \mathrm{H}\right.$, $\mathrm{H} \beta), 8.62\left(\mathrm{~d},{ }^{3} J_{\mathrm{H}, \mathrm{H}}=4.8 \mathrm{~Hz} 2 \mathrm{H}, \mathrm{H} \beta\right), 8.75\left(\mathrm{~d},{ }^{3} J_{\mathrm{H}, \mathrm{H}}=4.8 \mathrm{~Hz}, 2 \mathrm{H}, \mathrm{H} \beta\right), 9.14\left(\mathrm{~d},{ }^{3} J_{\mathrm{H}, \mathrm{H}}=\right.$ $4.8 \mathrm{~Hz}, 2 \mathrm{H}, \mathrm{H} \beta), 10.03\left(\mathrm{~s}, 1 \mathrm{H}, \mathrm{H}_{\text {meso }}\right) .{ }^{13} \mathrm{C}\left\{{ }^{1} \mathrm{H}\right\} \mathrm{NMR}\left(150 \mathrm{MHz}, \mathrm{CDCl}_{3}, 25^{\circ} \mathrm{C}\right): \delta_{\mathrm{c}} 21.48$ $\left(1 \mathrm{C}, p-\mathrm{CH}_{3}\right), 21.49\left(2 \mathrm{C}, o-\mathrm{CH}_{3}\right), 21.53\left(4 \mathrm{C}, o-\mathrm{CH}_{3}\right), 21.65\left(2 \mathrm{C}, p-\mathrm{CH}_{3}\right), 106.75(1 \mathrm{C}$, meso-C), 119.68 (2C, meso-C), 120.37 (1C, meso-C), 127.81 (2C, m-C $\left.\mathrm{C}_{\mathrm{Mes}}\right), 127.86(4 \mathrm{C}$, $m$ - $\left.\mathrm{C}_{\mathrm{Mes}}\right), 129.78$ (2C, $\beta$-C), 129.93 (2C, $\beta$-C), 129.99 (2C, $\beta$-C), 131.14 (2C, $\beta$-C), 137,51 (2C, $\left.\mathrm{C}_{\mathrm{Mes}}\right), 137.62$ (1C, $\left.\mathrm{C}_{\mathrm{Mes}}\right), 137.77$ (1C, $\left.\mathrm{C}_{\mathrm{Mes}}\right), 137.82$ (2C, $\left.\mathrm{C}_{\mathrm{Mes}}\right), 139.26$ (6C, o$\left.\mathrm{C}_{\mathrm{Mes}}\right), 140.23$ (2C, $\alpha$-C), 140.28 (2C, $\alpha$-C), 140.50 (2C, $\left.\alpha-\mathrm{C}\right), 140.55$ (2C, $\alpha$-C). HRMS (ESI): $m / z=857.30273\left([\mathrm{M}]^{+}\right.$, calcd. for $\left.\mathrm{C}_{47} \mathrm{H}_{42} \mathrm{~N}_{4} \mathrm{Pt} m / z=857.30555\right)$. UV-vis [toluene; $\lambda_{\max }, \mathrm{nm}(\log \varepsilon)$ ]: 397 (5.26), 506 (4.25), 536 (3.97). IR (neat, $\mathrm{cm}^{-1}$ ): $v_{\max } 2916(\mathrm{w}), 2852$ 
(w), $1727(\mathrm{w}), 1698(\mathrm{w}), 1610(\mathrm{w}), 1571(\mathrm{w}), 1542$ (w), 1452 (br, m), $1390(\mathrm{w}), 1375$ (w), 1348 (w), 1337 (w), $1311(\mathrm{~m}), 1269$ (w), 1243 (w), 1224 (w), $1215(\mathrm{w}), 1187(\mathrm{w})$, 1168 (w), 1067 (m), 1015 (s), 953 (w), 908 (w), 865 (w), 845 (m), 836 (s), 795 (s), 776 (m), $718(\mathrm{~s}), 693(\mathrm{~m}), 672(\mathrm{~m}), 648(\mathrm{w}), 595(\mathrm{w})$.

\section{[10-(diethoxyphosphoryl)-5,15-dimesitylporphyrinato]platinum(II)}

(PtDMesPP) was prepared from $25 \mathrm{mg}(0.037 \mathrm{mmol})$ of $\mathbf{H}_{2} \mathbf{D M e s P P}$ and $97 \mathrm{mg}(0.366$ mmol) of $\mathrm{PtCl}_{2}$ in $6 \mathrm{~mL}$ of benzonitrile. The reaction mixture was stirred under reflux for $8 \mathrm{~h}$. The resulting solid was purified by silica gel column chromatography and gel permeation chromatography using a $\mathrm{CH}_{2} \mathrm{Cl}_{2} / \mathrm{MeOH}(95: 5 \mathrm{v} / \mathrm{v})$ mixture and $\mathrm{CHCl}_{3}$ as eluent, respectively, to give PtDMesPP as a pink crystalline powder $(6 \mathrm{mg}, 18 \%) .{ }^{1} \mathrm{H}$ NMR $\left(600 \mathrm{MHz}, \mathrm{CDCl}_{3}, 25{ }^{\circ} \mathrm{C}\right): \delta_{\mathrm{H}} 1.36\left(\mathrm{t},{ }^{3} J_{\mathrm{H}, \mathrm{H}}=7.0 \mathrm{~Hz}, 6 \mathrm{H}, \mathrm{OCH}_{2} \underline{\mathrm{H}}_{3}\right), 1.85(\mathrm{~s}$, $\left.12 \mathrm{H}, o-\mathrm{CH}_{3}\right), 2.65\left(\mathrm{~s}, 6 \mathrm{H}, p-\mathrm{CH}_{3}\right), 4.20-4.28\left(\mathrm{~m}, 2 \mathrm{H}, \mathrm{OCH}_{2} \mathrm{CH}_{3}\right), 4.49-4.57(\mathrm{~m}, 2 \mathrm{H}$, $\left.\mathrm{OCH}_{2} \mathrm{CH}_{3}\right), 7.31$ (br s, $\left.4 \mathrm{H}, m-\mathrm{Ph}\right), 8.71\left(\mathrm{~d},{ }^{3} J_{\mathrm{H}, \mathrm{H}}=4.7 \mathrm{~Hz}, 2 \mathrm{H}, \mathrm{H} \beta\right), 8.77\left(\mathrm{~d},{ }^{3} J_{\mathrm{H}, \mathrm{H}}=5.3\right.$ $\mathrm{Hz}, 2 \mathrm{H}, \mathrm{H} \beta), 9.12\left(\mathrm{~d},{ }^{3} J_{\mathrm{H}, \mathrm{H}}=4.7 \mathrm{~Hz}, 2 \mathrm{H}, \mathrm{H} \beta\right), 10.06\left(\mathrm{~s}, 1 \mathrm{H}, \mathrm{H}_{\text {meso }}\right), 10.34\left(\mathrm{~d},{ }^{3} J_{\mathrm{H}, \mathrm{H}}=5.1\right.$ $\mathrm{Hz}, 2 \mathrm{H}, \mathrm{H} \beta) .{ }^{31} \mathrm{P}\left\{{ }^{1} \mathrm{H}\right\}$ NMR $\left(600 \mathrm{MHz}, \mathrm{CDCl}_{3}, 25{ }^{\circ} \mathrm{C}\right): \delta_{\mathrm{P}} 21.98 .{ }^{13} \mathrm{C}\left\{{ }^{1} \mathrm{H}\right\} \mathrm{NMR}(150$ $\left.\mathrm{MHz}, \mathrm{CDCl}_{3}, 25{ }^{\circ} \mathrm{C}\right): \delta_{\mathrm{c}} 16.46\left(\mathrm{~d},{ }^{2} J_{\mathrm{C}, \mathrm{P}}=7.2 \mathrm{~Hz}, 2 \mathrm{C}, \mathrm{OCH}_{2} \underline{\mathrm{CH}}_{3}\right), 21.49\left(6 \mathrm{C}, p+o-\mathrm{CH}_{3}\right)$, $62.83\left(\mathrm{~d},{ }^{2} J_{\mathrm{C}, \mathrm{P}}=4.5 \mathrm{~Hz}, 2 \mathrm{C}, \mathrm{OCH}_{2} \mathrm{CH}_{3}\right), 103.19\left(\mathrm{~d},{ }^{2} J_{\mathrm{C}, \mathrm{P}}=185.7 \mathrm{~Hz}, 1 \mathrm{C}\right.$, meso-C), 109.93 (1C, meso-C), 120.71 (2C, meso-C), 127.95 (4C, m-C $\mathrm{C}_{\mathrm{Mes}}$ ), 129.57 (2C, $\beta$-C), 131.25 (2C, $\beta$-C), 132.23 (2C, $\beta$-C), 132.85 (2C, $\beta$-C), 137.22 (2C, $\left.\mathrm{C}_{\mathrm{Mes}}\right), 138.07$ (2C, $\mathrm{C}_{\mathrm{Mes}}$ ), 139.07 (4C,o-C $\left.\mathrm{C}_{\mathrm{Mes}}\right), 139.68(2 \mathrm{C}, \alpha-\mathrm{C}), 140.20$ (2C, $\left.\alpha-\mathrm{C}\right), 141.71(2 \mathrm{C}, \alpha-\mathrm{C})$, $143.21\left(\mathrm{~d},{ }^{2} J_{\mathrm{C}, \mathrm{P}}=17.8 \mathrm{~Hz}, 2 \mathrm{C}, \alpha-\mathrm{CP}\right)$. HRMS (ESI): $m / z=898.24236\left([\mathrm{M}+\mathrm{Na}]^{+}\right.$, calcd. for $\left.\mathrm{C}_{42} \mathrm{H}_{41} \mathrm{~N}_{4} \mathrm{O}_{3} \mathrm{PPtNa} m / z=898.24597\right)$. UV-vis [toluene; $\lambda_{\max }, \mathrm{nm}(\log \varepsilon)$ ]: 394 (5.32), 510 (4.12), 545 (4.32). IR (neat, $\mathrm{cm}^{-1}$ ): $v_{\max } 2976(\mathrm{w}), 2919(\mathrm{w}), 2855(\mathrm{w}), 1726(\mathrm{w})$, 1610 (w), 1563 (w), 1543 (w), 1454 (m), 1440 (m), 1390 (w), 1377 (w), 1361 (w), 1333 (w), $1301(\mathrm{w}), 1254(\mathrm{~m}), 1218(\mathrm{w}), 1165$ (w), 1087 (w), 1067 (m), 1044 (m), 1017 (s), 961 (br, m), $884(\mathrm{~m}), 856(\mathrm{~m}), 837(\mathrm{w}), 800(\mathrm{~m}), 736(\mathrm{w}), 725(\mathrm{w}), 712(\mathrm{w}), 696(\mathrm{w})$, $603(\mathrm{~m}), 578(\mathrm{w}), 562(\mathrm{~m}), 542(\mathrm{w})$.

\section{[10-(diethoxyphosphoryl)-5,15,20-trimesitylporphyrinato]platinium(II)}

(PtTMesPP) was prepared from $10 \mathrm{mg}(0.013 \mathrm{mmol})$ of H2TMesPP, $33 \mathrm{mg}(0.124$ mmol $)$ of $\mathrm{PtCl}_{2}$ and $10 \mathrm{mg}(0.122 \mathrm{mmol}) \mathrm{NaOAc}$ in $3 \mathrm{~mL}$ of benzonitrile according to the general procedure. The reaction mixture was stirred at $150{ }^{\circ} \mathrm{C}$ for $1 \mathrm{~h}$. The resulting solid was purified by silica gel column chromatography and gel permeation chromatography using $\mathrm{CH}_{2} \mathrm{Cl}_{2} / \mathrm{MeOH}(95: 5 \mathrm{v} / \mathrm{v})$ mixture and $\mathrm{CHCl}_{3}$ as eluent, respectively, to give PtTMesPP as pink crystalline powder (11 mg, 89\%). ${ }^{1} \mathrm{H}$ NMR (600 
$\left.\mathrm{MHz}, \mathrm{CDCl}_{3}, 25^{\circ} \mathrm{C}\right): \delta_{\mathrm{H}} 1.35\left(\mathrm{t},{ }^{3} J_{\mathrm{H}, \mathrm{H}}=6.9 \mathrm{~Hz}, 6 \mathrm{H}, \mathrm{OCH}_{2} \mathrm{CH}_{3}\right), 1.87\left(\mathrm{~s}, 12 \mathrm{H}, o-\mathrm{CH}_{3}\right)$, $1.88\left(\mathrm{~s}, 6 \mathrm{H}, o-\mathrm{CH}_{3}\right), 2.62\left(\mathrm{~s}, 3 \mathrm{H}, p-\mathrm{CH}_{3}\right), 2.64\left(\mathrm{~s}, 6 \mathrm{H}, p-\mathrm{CH}_{3}\right), 4.17-4.25(\mathrm{~m}, 2 \mathrm{H}$, $\left.\mathrm{OC}_{2} \underline{C H}_{3}\right), 4.47-4.55\left(\mathrm{~m}, 2 \mathrm{H}, \mathrm{OC}_{2} \mathrm{CH}_{3}\right), 7.28$ (br s, $\left.6 \mathrm{H}, m-\mathrm{Ph}\right), 8.53\left(\mathrm{~d},{ }^{3} J_{\mathrm{H}, \mathrm{H}}=4.8\right.$ $\mathrm{Hz}, 2 \mathrm{H}, \mathrm{H} \beta), 8.56\left(\mathrm{~d},{ }^{3} J_{\mathrm{H}, \mathrm{H}}=4.8 \mathrm{~Hz}, 2 \mathrm{H}, \mathrm{H} \beta\right), 8.71\left(\mathrm{~d},{ }^{3} J_{\mathrm{H}, \mathrm{H}}=5.2 \mathrm{~Hz}, 2 \mathrm{H}, \mathrm{H} \beta\right), 10.28$ $\left(\mathrm{d},{ }^{3} J_{\mathrm{H}, \mathrm{H}}=5.2 \mathrm{~Hz}, 2 \mathrm{H}, \mathrm{H} \beta\right) .{ }^{31} \mathrm{P}\left\{{ }^{1} \mathrm{H}\right\} \mathrm{NMR}\left(600 \mathrm{MHz}, \mathrm{CDCl}_{3}, 25{ }^{\circ} \mathrm{C}\right): \delta_{\mathrm{P}} 22.09 .{ }^{13} \mathrm{C}\left\{{ }^{1} \mathrm{H}\right\}$ $\operatorname{NMR}\left(150 \mathrm{MHz}, \mathrm{CDCl}_{3}, 25^{\circ} \mathrm{C}\right): \delta_{\mathrm{c}} 16.44\left(\mathrm{~d},{ }^{2} J_{\mathrm{C}, \mathrm{P}}=6.6 \mathrm{~Hz}, 2 \mathrm{C}, \mathrm{OCH}_{2} \underline{\mathrm{CH}}_{3}\right), 21.46(1 \mathrm{C}$, $\left.p-\mathrm{CH}_{3}\right), 21.47\left(2 \mathrm{C}, o-\mathrm{CH}_{3}\right), 21.51\left(4 \mathrm{C}, o-\mathrm{CH}_{3}\right), 21.56\left(2 \mathrm{C}, p-\mathrm{CH}_{3}\right), 62.75\left(\mathrm{~d},{ }^{2} J_{\mathrm{C}, \mathrm{P}}=4.9\right.$ $\left.\mathrm{Hz}, 2 \mathrm{C}, \mathrm{O}_{\mathrm{CH}_{2}} \mathrm{CH}_{3}\right), 102.54$ (d, ${ }^{2} J_{\mathrm{C}, \mathrm{P}}=185.6 \mathrm{~Hz}, 1 \mathrm{C}$, meso-C), 121.01 (2C, meso-C), 123.41 (1C, meso-C), 127.86 (2C, $m$ - $\mathrm{C}_{\mathrm{Mes}}$ ), 127.90 (4C, $m$-C $\mathrm{C}_{\mathrm{Mes}}$ ), 129.38 (2C, $\beta$-C), $130.86\left(2 \mathrm{C}, \beta\right.$-C), 131.24 (2C, $\beta$-C), 132.59 (2C, $\beta$-C), 137.00 (1C, $\mathrm{C}_{\mathrm{Mes}}$ ), 137.33 (2C,

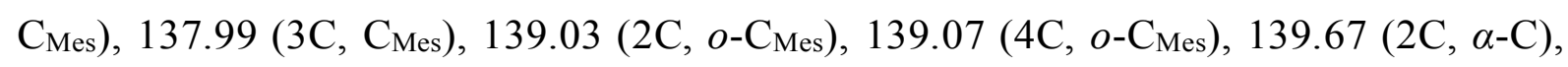
$140.01(2 \mathrm{C}, \alpha-\mathrm{C}), 141.74(2 \mathrm{C}, \alpha-\mathrm{C}), 143.44\left(\mathrm{~d},{ }^{2} J_{\mathrm{C}, \mathrm{P}}=18.5 \mathrm{~Hz}, 2 \mathrm{C}, \alpha-\mathrm{CP}\right)$. HRMS (ESI): $m / z=993.33999\left([\mathrm{M}]^{+}\right.$, calcd. for $\left.\mathrm{C}_{51} \mathrm{H}_{51} \mathrm{~N}_{4} \mathrm{O}_{3} \mathrm{PPt} \mathrm{m} / z=993.33448\right), 1016.32463$ $\left([\mathrm{M}+\mathrm{Na}]^{+}\right.$, calcd. for $\left.\mathrm{C}_{51} \mathrm{H}_{51} \mathrm{~N}_{4} \mathrm{O}_{3} \mathrm{PPtNa} m / z=1016.32387\right)$. UV-vis [toluene; $\lambda_{\max }, \mathrm{nm}$ (log $\varepsilon$ )]: 402 (5.13), 515 (4.07), 549 (3.97). IR (neat, $\mathrm{cm}^{-1}$ ): $v_{\max } 2956$ (s), 2924 (s), 2857 (m), 1726 (s), 1610 (w), 1579 (w), 1542 (w), 1457 (br, m), 1377 (w), 1354 (w), 1338 (w), 1273 (br, m), 1209 (w), 1162 (w), 1122 (m), 1072 (m), 1041 (m), 1019 (s), 962 (br, m), $885(\mathrm{w}), 865(\mathrm{w}), 853(\mathrm{w}), 833(\mathrm{w}), 801(\mathrm{~m}), 741(\mathrm{~m}), 728(\mathrm{w}), 712(\mathrm{~m}), 651(\mathrm{w})$, $601(\mathrm{~m}), 563(\mathrm{~m}), 541(\mathrm{w})$.

\section{Photophysical measurements}

Photophysical solution studies were performed for dye concentrations ranging between 3 and $7 \mu \mathrm{M}$. Luminescence spectra were recorded on a FluoroLog ${ }^{\circledR} 3$ spectrofluorometer (Horiba Scientific) equipped with a NIR-sensitive R2658 photomultiplier from Hamamatsu (300-1050 nm). All dye solutions were deoxygenated in a screw-cap cuvette (Hellma) by bubbling high purity nitrogen (99.9999\%) through the solution for at least $15 \mathrm{~min}$. Absolute quantum yields at room temperature were measured with an integrating sphere from Horiba. The luminescence decay times were acquired in the time domain on the FluoroLog ${ }^{\circledR} 3$ spectrofluorometer equipped with a DeltaHub module (Horiba Scientific) controlling a SpectraLED-392 $(\lambda=392 \mathrm{~nm}$ ) and using DAS-6 Analysis software for data analysis. For characterization of the oxygen sensing properties, the composition of the gas was adjusted with a custom-build gasmixing device based on mass-flow controllers from Voegtlin (www.red-y.com) by 
mixing compressed air and dinitrogen. The luminescence spectra and phosphorescence decay times at $77 \mathrm{~K}$ were recorded for the dye solutions in a mixture of toluene and tetrahydrofuran $(4: 6 \mathrm{v} / \mathrm{v})$, which produces good glasses at this temperature. The measurements were made in the Institute of Analytical Chemistry and Food Chemistry, Graz University of Technology.

\section{Photostability studies}

Photostability measurements were conducted in a $100 \mathrm{~mL}$ double-jacketed glass vessel equipped with a magnetic stirring bar and fitted to a Lauda RE106 water circulator ensuring a constant temperature of $25.0(5){ }^{\circ} \mathrm{C}$. The cell was sealed with a 5-necked lid from Metrohm (reference 6.1414.010) fitted with a thermometer and an immersion probe having a $1 \mathrm{~cm}$ optical path length made of Suprasil 300 (Hellma, reference 6610202). The probe was connected to a Cary 50 (Varian) spectrophotometer through fiber guides and a fiber optic coupler. Prior to each experiment, the reference spectrum was recorded with the pure solvent and the absorbance set to zero at the wavelength used to monitor the time course of the reaction. Visible absorption spectra were recorded over the 350 $800 \mathrm{~nm}$ range by taking a point at each nanometer at a scan rate of $400 \mathrm{~nm} / \mathrm{min}$. Kinetic traces were recorded at the maximum of the Soret band with an average time of $0.1 \mathrm{~s}$ by taking one point every minute until the end of the reaction (typically, 5000-7000 min). A spectrum was recorded systematically before and after irradiation. The light source was an Osram Powerstat HQI BT $400 \mathrm{~W}$ lamp (metal halogenide lamp with UV filter) emitting in the visible range (the spectrum of the lamp provided by the manufacturer is displayed in Figure S79, ESI) and was placed in a fixed position $20 \mathrm{~cm}$ away from the glass reactor, both devices being aligned with respect to their centers. The setup remained untouched during all experiments to ensure reproducibility, while the lamp was allowed to warm up and to stabilize for at least half an hour before starting the experiments. In most cases however, it remained switched on in between the irradiations. During filling/emptying operations and before exposing the porphyrin solution to the light once it was introduced in the cell, the latter was protected by an UV filtering Plexiglas screen covered with an aluminum foil.

All solutions of porphyrins were freshly prepared by carefully weighing a few milligrams of solid with a Mettler-Toledo XP205 Delta Range balance (resolution: 0.01 $\mathrm{mg}$ ) into a $5 \mathrm{~mL}$ volumetric flask. Compounds were dissolved in analytical grade DMF 
(Sigma-Aldrich) dried over molecular sieves or toluene (Sigma-Aldrich) dried over $\mathrm{Al}_{2} \mathrm{O}_{3}$ and the resulting solutions were stored in the dark. In few instances, short (less than $1 \mathrm{~min}$ ) sonication was required. The reactor was filled with $50 \mathrm{~mL}$ of solvent using a glass pipet and allowed to reach the equilibrium temperature. After performing the zeroing operations of the spectrophotometer, an aliquot of the porphyrin mother solution was injected in the reactor with a 1000 L Eppendorf micropipette; the introduced volume was calculated so that the final concentration after dilution was $5 \mu \mathrm{M}$ unless otherwise noted. Immediately after, a spectrum was measured while protecting the cell with the screen. At the end of the data collection, the cell was exposed to the light source while starting the recording of the absorbance decay curve. Data manipulation and nonlinear least-squares fitting to a monoexponential decay function $\left[y=a \exp \left(-k_{o b s} t\right)+\right.$ $b t+c]$ were performed with Origin 8.0 (Figure S83-S85, ESI).

\section{Conflicts of interest}

There are no conflicts to declare.

\section{Acknowledgements}

This work was supported by the Russian Foundation for Basic Research (grant number 1833-00734-mol-a), the Russian Academy of Sciences (RAS), and the Centre National de la Recherche Scientifique (CNRS). It was carried out in the framework of the International Associated French-Russian Laboratory of Macrocyclic Systems and Related Materials (LAMREM) of CNRS and RFBR (RFBR grant number 17-53-16028). Some measurements were performed using equipment of CKP FMI IPCE RAS. Prof. Anthony Romieu is warmly acknowledged for helpful discussions concerning this work. We are also grateful to Marie-José Penouilh and Quentin Bonnin for their technical assistance.

\section{Notes and references}

1 M. Quaranta, S. M. Borisov and I. Klimant, Bioanal. Rev., 2012, 4, 115-157.

2 J.A. Gareth Williams, S. Develay, D. Rochester and L. Murphy, Coord. Chem. Rev., 2008, 252, 25962611.

3 M. J. Currie, J. K. Mapel, T. D. Heidel, S. Goffri and M. A. Baldo, Science, 2008, 321, 226-228.

4 M. DeRosa, Coord. Chem. Rev., 2002, 233-234, 351-371.

5 A. Maldotti, L. Andreotti, A. Molinari, S. Borisov and V. Vasil'ev, Chem. - Eur. J., 2001, 7, 3564-3571. 
R. I. Dmitriev, H. M. Ropiak, G. V. Ponomarev, D. V. Yashunsky and D. B. Papkovsky, Bioconjug. Chem., 2011, 22, 2507-2518.

X. D. Wang and O. S. Wolfbeis, Chem. Soc. Rev., 2014, 43, 3666-3761.

O. S. Wolfbeis, J. Mater. Chem., 2005, 15, 2657-2669.

I. Dunphy, S. A. Vinogradov and D. F. Wilson, Anal. Biochem., 2002, 310, 191-198.

S. M. Borisov, in Quenched-phosphorescence Detection of Molecular Oxygen: Applications in Life Sciences, ed. D. B. Papkovsky and R. I. Dmitriev, Royal Society of Chemistry, 2018, 1-18.

N. Asakura and I. Okura, in Molecular Catalysts for Energy Conversion, ed. T. Okada and M. Kaneko, Springer, Berlin Heidelberg, 2008, 299-328.

Q. Zheng and L. D. Lavis, Curr. Opin. Chem. Biol., 2017, 39, 32-38.

A. K. Bansal, W. Holzer, A. Penzkofer and T. Tsuboi, Chem. Phys., 2006, 330, 118-129.

K. Koren, S. M. Borisov, R. Saf and I. Klimant, Eur. J. Inorg. Chem., 2011, 1531-1534. Y. Amao, T. Miyashita and I. Okura, Analyst, 2000, 125, 871-875.

K. Ozette, P. Leduc, M. Palacio, J.-F. Bartoli, K. M. Barkigia, J. Fajer, P. Battioni and D. Mansuy, J. Am. Chem. Soc., 1997, 119, 6442-6443.

A. Giraudeau, A. Louati, H. J. Callot and M. Gross, Inorg. Chem., 1981, 20, 769-772.

P. Bhyrappa and V. Krishnan, Inorg. Chem., 1991, 30, 239-245.

S. W. Lai, Y. J. Hou, C. M. Che, H. L. Pang, K. Y. Wong, C. K. Chang and N. Zhu, Inorg. Chem., 2004, 43, 3724-3732.

C. M. Che, Y. J. Hou, M. C. W. Chan, J. Guo, Y. Liu and Y. Wang, J. Mater. Chem., 2003, 13, 13621366.

S. K. Lee and I. Okura, Anal. Commun., 1997, 34, 185-188.

C. M. B. Carvalho, T. J. Brocksom and K. T. de Oliveira, Chem. Soc. Rev., 2013, 42, 3302-3317.

F. Niedermair, S. M. Borisov, G. Zenkl, O. T. Hofmann, H. Weber, R. Saf and I. Klimant, Inorg. Chem., 2010, 49, 9333-9342.

S. M. Borisov, G. Nuss, W. Haas, R. Saf, M. Schmuck and I. Klimant, J. Photochem. Photobiol., A., 2009, 201, 128-135.

P. W. Zach, S. A. Freunberger, I. Klimant and S. M. Borisov, ACS Appl. Mater. Interfaces, 2017, 9, 3800838023.

Y. Y. Enakieva, A. G. Bessmertnykh, Y. G. Gorbunova, C. Stern, Y. Rousselin, A. Y. Tsivadze and R. Guilard, Org. Lett., 2009, 11, 3842-3845.

Y. Matano, K. Matsumoto, Y. Terasaka, H. Hotta, Y. Araki, O. Ito, M. Shiro, T. Sasamori, N. Tokitoh and H. Imahori, Chem. - Eur. J., 2007, 13, 891-901.

29 Y. Y. Enakieva, J. Michalak, I. A. Abdulaeva, M. V. Volostnykh, C. Stern, R. Guilard, A. G. Bessmertnykh-Lemeune, Y. G. Gorbunova, A. Y. Tsivadze and K. M. Kadish, Eur. J. Org. Chem., 2016, 2016, 4881-4892.

30 Y. Y. Enakieva, M. V. Volostnykh, S. E. Nefedov, G. A. Kirakosyan, Y. G. Gorbunova, A. Y. Tsivadze, A. G. Bessmertnykh-Lemeune, C. Stern and R. Guilard, Inorg. Chem., 2017, 56, 3055-3070. 
P. Chen, A. Bessmertnykh-Lemeune, C. Stern and R. Guilard, Inorg. Chem., 2013, 52, 999-1008.

Y. Fang, Y. G. Gorbunova, P. Chen, X. Jiang, M. Manowong, A. A. Sinelshchikova, Y. Y. Enakieva, A. G. Martynov, A. Y. Tsivadze, A. Bessmertnykh-Lemeune, C. Stern, R. Guilard and K. M. Kadish, Inorg. Chem., 2015, 54, 3501-3512.

Y. Fang, K. M. Kadish, P. Chen, Y. Gorbunova, Y. Enakieva, A. Tsivadze, A. Bessmertnykh-Lemeune and R. Guilard, J. Porphyrins Phthalocyanines, 2013, 17, 1035-1045.

a) K. M. Kadish, P. Chen, Y. Y. Enakieva, S. E. Nefedov, Y. G. Gorbunova, A. Y. Tsivadze, A. Bessmertnykh-Lemeune, C. Stern and R. Guilard, J. Electroanal. Chem., 2011, 656, 61-71; (b) Y. Fang, X. Jiang, K. M. Kadish, S.E. Nefedov, G. A. Kirakosyan, Y. Y. Enakieva, Y. G. Gorbunova, A. Y. Tsivadze, C. Stern, A. Bessmertnykh-Lemeune, and R. Guilard, Inorg. Chem., 2019, 58, 4665-4678.; c) S.E. Nefedov, K.P.Birin, A. Bessmertnykh-Lemeune, Y. Y. Enakieva, A.A. Sinelshchikova, Y. G. Gorbunova, A. Y. Tsivadze, C. Stern, Y. Fang, K. M. Kadish, Dalton Trans., 2019, 48, 5372-5383.

C. Stern, A. Bessmertnykh-Lemeune, Y. Gorbunova, A. Tsivadze and R. Guilard, Turk. J. Chem., 2014, 38, 980-993.

P. G. Mingalyov and G. V Lisichkin, Russ. Chem. Rev., 2006, 75, 541-557.

C. Queffélec, M. Petit, P. Janvier, D. A. Knight and B. Bujoli, Chem. Rev., 2012, 112, 3777-3807. Y.-P. Zhu, T.-Z. Ren and Z.-Y. Yuan, Catal. Sci. Technol., 2015, 5, 4258-4279.

A. Cattani-Scholz, ACS Appl. Mater. Interfaces, 2017, 9, 25643-25655.

G. Guerrero, J. G. Alauzun, M. Granier, D. Laurencin and P. H. Mutin, Dalton Trans., 2013, 42, 1256912585.

C. M. Lemon, E. Karnas, M. G. Bawendi and D. G. Nocera, Inorg. Chem., 2013, 52, 10394-10406. Y. Amao, K. Miyakawa and I. Okura, J. Mater. Chem., 2000, 10, 305-308.

C. O. Obondi, G. N. Lim and F. D’Souza, J. Phys. Chem. C, 2015, 119, 176-185.

I. D. Kostas, A. G. Coutsolelos, G. Charalambidis and A. Skondra, Tetrahedron Lett., 2007, 48, 66886691.

R. I. Zubatyuk, A. a Sinelshchikova, Y. Y. Enakieva, Y. G. Gorbunova, A. Y. Tsivadze, S. E. Nefedov, A. Bessmertnykh-Lemeune, R. Guilard and O. V. Shishkin, CrystEngComm, 2014, 16, 10428-10438.

M. Zeng, Y. Du, L. Shao, C. Qi and X. M. Zhang, J. Org. Chem., 2010, 75, 2556-2563.

C. Huo, H. Zhang, J. Guo, H. Zhang, P. Zhang and Y. Wang, Chinese Sci. Bull., 2006, 51, 2327-2334.

W. Zhuang, Y. Zhang, Q. Hou, L. Wang and Y. Cao, J. Polym. Sci. Part A Polym. Chem., 2006, 44, 41744186.

W. Wu, S. Ji, H. Guo, X. Wang and J. Zhao, Dyes Pigm., 2011, 89, 199-211.

50 Q. Ouyang, K. Q. Yan, Y. Z. Zhu, C. H. Zhang, J. Z. Liu, C. Chen and J. Y. Zheng, Org. Lett., 2012, 14, 2746-2749.

51 M. Shmilovits, M. Vinodu and I. Goldberg, Cryst. Growth Des., 2004, 4, 633-638.

52 E. B. Fleischer, C. K. Miller and L. E. Webb, J. Am. Chem. Soc., 1964, 86, 2342-2347.

53 M. A. Uvarova, A. A. Sinelshchikova, M. A. Golubnichaya, S. E. Nefedov, Y. Y. Enakieva, Y. G. Gorbunova, A. Y. Tsivadze, C. Stern, A. Bessmertnykh-Lemeune and R. Guilard, Cryst. Growth Des., 2014, 14, 5976-5984. 
D. R. Kearns, Chem. Rev., 1971, 71, 395-427.

W. P. To, Y. Liu, T. C. Lau and C. M. Che, Chem. - Eur. J., 2013, 19, 5654-5664.

A. Mills, Chem. Soc. Rev., 2005, 34, 1003-1011.

Q. Zheng, M. F. Juette, S. Jockusch, M. R. Wasserman, Z. Zhou, R. B. Altman and S. C. Blanchard, Chem. Soc. Rev., 2014, 43, 1044-1056.

X. Wu and W. Zhu, Chem. Soc. Rev., 2015, 44, 4179-4184.

61

O. Redy-Keisar, K. Huth, U. Vogel, B. Lepenies, P. H. Seeberger, R. Haag and D. Shabat, Org. Biomol. Chem., 2015, 13, 4727-4732.

C. S. Chu and Y. L. Lo, Sens. Actuators, B, 2008, 134, 711-717.

S. H. Huang, C. H. Tsai, C. W. Wu and C. J. Wu, Sens. Actuators, A, 2011, 165, 139-146.

X. Zhou, F. Su, Y. Tian, R. H. Johnson and D. R. Meldrum, Sens. Actuators, B, 2011, 159, 135-141.

R. J. Meier, S. Schreml, X. D. Wang, M. Landthaler, P. Babilas and O. S. Wolfbeis, Angew. Chem. Int. Ed., 2011, 50, 10893-10896.

K. Koren, S. M. Borisov and I. Klimant, Sens. Actuators, B, 2012, 169, 173-181.

S. Lu, W. Xu, Y. Chen, Y. Jiang, Q. Yao, F. Luo, Y. Wang and X. Chen, Sens. Actuators, B, 2016, 232, 585-594.

B. W. Atwater, J. Fluoresc., 1992, 2, 237-246.

R. Słota and G. Dyrda, Inorg. Chem., 2003, 42, 5743-5750.

A. Samanta, M. Vendrell, R. Das and Y.-T. Chang, Chem. Commun., 2010, 46, 7406-7408.

W. L. Armarego and D. D. Perrin, Purification of Laboratory Chemicals, Butterworth-Heinemann, Oxford, 4th ed., 1997.

SAINT-Plus V7.68, 1998, Bruker AXS Inc., Madison, WI-53719, USA.

G.M. Sheldrick, SADABS, 1997, Bruker AXS Inc.,Madison, WI-53719,USA.

G. M. Sheldrick, Acta Crystallogr. A, 2015, 71, 3-8.

G. M. Sheldrick, Acta Crystallogr. C, 2015, 71, 3-8.

O. V Dolomanov, L. J. Bourhis, R. J. Gildea, J. A. K. Howard and H. Puschmann, J. Appl. Crystallogr., 2009, 42, 339-341.

Q. M. Wang and D. W. Bruce, Synlett, 1995, 1267-1268.

78 J. K. Laha, S. Dhanalekshmi, M. Taniguchi, A. Ambroise and J. S. Lindsey, Org. Process Res. Dev., 2003, 7, 799-812.

B. Habermeyer, A. Takai, C. P. Gros, M. El Ojaimi, J.-M. Barbe and S. Fukuzumi, Chem. - Eur. J., 2011, 17, 10670-10681.

J. S. Manka and D. S. Lawrence, Tetrahedron Lett., 1989, 30, 6989-6992.

81 K. Lu, C. He and W. Lin, J. Am. Chem. Soc., 2014, 136, 16712-16715.

82 L. Yu, K. Muthukumaran, I. V. Sazanovich, C. Kirmaier, E. Hindin, J. R. Diers, P. D. Boyle, D. F. Bocian, D. Holten and J. S. Lindsey, Inorg. Chem., 2003, 42, 6629-6647.

83 S. Arrechea, A. Molina-Ontoria, A. Aljarilla, P. de la Cruz, F. Langa and L. Echegoyen, Dye. Pigment., 2015, 121, 109-117. 
